Review

\title{
Recent Advancements in Polysulfone Based Membranes for Fuel Cell (PEMFCs, DMFCs and AMFCs) Applications: A Critical Review
}

\author{
Rajangam Vinodh ${ }^{1,+} \mathbb{D}$, Raji Atchudan ${ }^{2,+} \mathbb{D}$, Hee-Je Kim ${ }^{3, *}$ and Moonsuk Yi $^{1, *}$ \\ 1 Department of Electronics Engineering, Pusan National University, Busan 46241, Korea; \\ vinoth6482@gmail.com \\ 2 Department of Chemical Engineering, Yeungnam University, Gyeongsan 38541, Korea; atchudanr@yu.ac.kr \\ 3 Department of Electrical and Computer Engineering, Pusan National University, Busan 46241, Korea \\ * Correspondence: heeje@pusan.ac.kr (H.-J.K.); msyi@pusan.ac.kr (M.Y.) \\ + These authors contributed equally to this work.
}

Citation: Vinodh, R.; Atchudan, R.; Kim, H.-J.; Yi, M. Recent

Advancements in Polysulfone Based Membranes for Fuel Cell (PEMFCs,

DMFCs and AMFCs) Applications: A Critical Review. Polymers 2022, 14, 300. https://doi.org/10.3390/ polym 14020300

Academic Editor: Vincenzo Baglio

Received: 10 December 2021

Accepted: 10 January 2022

Published: 12 January 2022

Publisher's Note: MDPI stays neutral with regard to jurisdictional claims in published maps and institutional affiliations.

Copyright: (C) 2022 by the authors. Licensee MDPI, Basel, Switzerland. This article is an open access article distributed under the terms and conditions of the Creative Commons Attribution (CC BY) license (https:// creativecommons.org/licenses/by/ $4.0 /)$.

\begin{abstract}
In recent years, ion electrolyte membranes (IEMs) preparation and properties have attracted fabulous attention in fuel cell usages owing to its high ionic conductivity and chemical resistance. Currently, perfluorinatedsulfonicacid (PFSA) membrane has been widely employed in the membrane industry in polymer electrolyte membrane fuel cells (PEMFCs); however, Nafion ${ }^{\mathrm{TM}}$ suffers reduced proton conductivity at a higher temperature, requiring noble metal catalyst ( $\mathrm{Pt}, \mathrm{Ru}$, and $\mathrm{Pt}-\mathrm{Ru})$, and catalyst poisoning by CO. Non-fluorinated polymers are a promising substitute. Polysulfone (PSU) is an aromatic polymer with excellent characteristics that have attracted membrane scientists in recent years. The present review provides an up-to-date development of PSU based electrolyte membranes and its composites for PEMFCs, alkaline membrane fuel cells (AMFCs), and direct methanol fuel cells (DMFCs) application. Various fillers encapsulated in the PEM/AEM moiety are appraised according to their preliminary characteristics and their plausible outcome on PEMFC/DMFC/AMFC. The key issues associated with enhancing the ionic conductivity and chemical stability have been elucidated as well. Furthermore, this review addresses the current tasks, and forthcoming directions are briefly summarized of PEM/AEMs for PEMFCs, DMFCs, AMFCs.
\end{abstract}

Keywords: polysulfone; polymer electrolyte membrane; DMFCs; AMFCs; sulfonation; Nafion ${ }^{\mathrm{TM}}$; fillers; inorganic/organic hybrid membranes

\section{Introduction \\ 1.1. Fuel Cells}

The fuel cell is an electro-chemical energy conversion design; it alters the chemical energy of the reactants directly into electric energy along with heat and potable water. As global environmental and energy issues become more and more acute, incredible efforts are being made to explore new energy selections. As a new energy technology, fuel cells have been shown to be highly efficient and have an excellent ability to convert conventional fossil fuel energies due to low or zero-emission [1-3]. Fuel cells and batteries share multiple similarities: both are based on the anode-to-cathode electronic transfer principle and convert chemical energy into electric energy; they both require an electrolyte and external load to perform useful work and generate low DC voltages. Fuel cells are stacked similarly to batteries as well. Extensive power and voltage output is achieved by combining many cells in series. The main differences between fuel cells and batteries are the nature of their electrodes. Batteries use metallic anodes (lithium or zinc) and cathodes (generally metallic oxides). During operation, batteries consume the anode and the cathode, which will need recharge or replacement. In contrast, fuel cells operate with externally supplied reactants and do not consume any part working part of the cell. Therefore, fuel cells need no recharge 
and can continue operating as long as the reactant is supplied. Such repeated charging and discharging resulted in decreasing the life-time of the battery compared to that in the case of the fuel cell. In addition, fuel cells provide an inherently clean source of energy, with no adverse environmental impact during operation, as the byproducts are simply heat and water [4]. Nevertheless, the recent constraint in fuel cell commercialization stalks from the expensive nature of the raw materials (Nafion ${ }^{\mathrm{TM}}$ electrolyte membrane and noble metal catalysts) and of the manufacturing method [5]. Furthermore, fuel cell electric vehicles (FCEV) are under progress by many automobile companies and are effectively verified due to their several advantages. Even though many advantages are in the fuel cells, there is a gap in the implementation of the fuel cells in on-road vehicles due to some practical issues.

\subsection{Types of FCs}

Fuel cells are divided into direct and indirect fuel cells according to their working temperature, the fuel cell components, and the type of electrolytes used. Fuel cells are classified according to their operational temperatures, such as low-temperature fuel cells and high-temperature fuel cells, as shown in Figure 1a [6]. The PEMFC, AMFC, and DMFC belong to low-temperature fuel cells. Molten carbonate fuel cell (MCFC), phosphoric acid fuel cell (PAFC), and solid oxide fuel cell (SOFC), fall into the high-temperature fuel cells group. In this cataloging, PEMFCs are more promising and consistent than other fuel cells owing to their versatile applications, extraordinary efficacy, and tiny emission of impurities, and can be the basis for DMFCs and AFCs. The acidic or alkaline concentrations are applied as electrolytes in fuel cells termed as mobile electrolyte systems, whereas electrolytes are immersed in a porous-based (pores enriched) material, defined as an inert/immobile electrolyte system or matrix system [7-10].

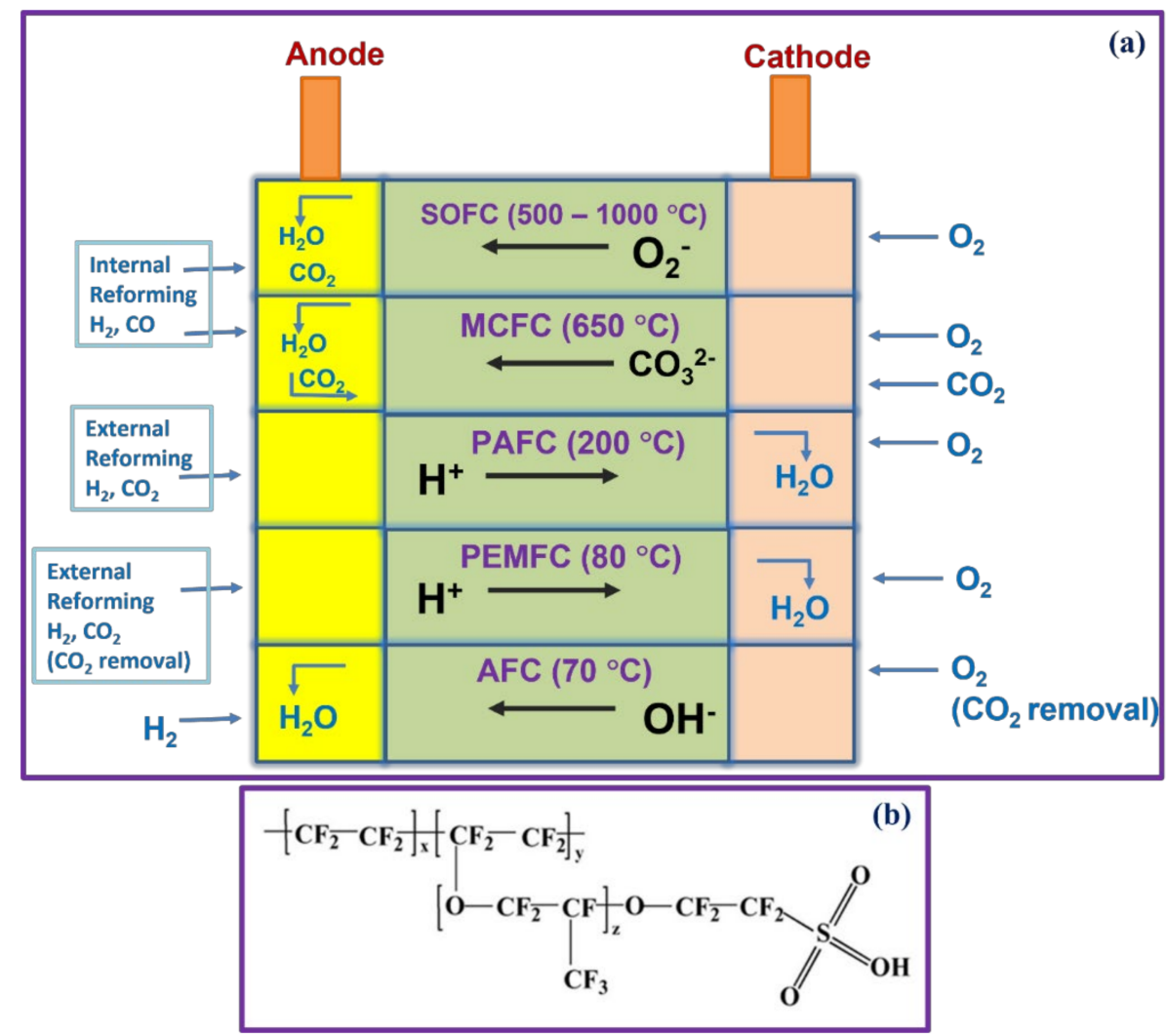

Figure 1. (a) Different types of fuel cell; (b) structure of PFSA.

\subsubsection{PEMFCs}

In a typical PEMFC, the cation exchange membrane (CEM or PEM) is accountable for the proton conductivity, which permits the passage of $\mathrm{H}^{+}$from anode to the cathode, 
establishing the essential component of the electrochemical device. In various types of fuel cells, membranes constructed with perfluorinatedsulfonicacid (PFSA) is predominantly employed because of its excellent proton conductivity and adequate chemical/mechanical characteristics; they are worked at temperatures between 120 and $180{ }^{\circ} \mathrm{C}$ in high pressure [11,12]. The structure of PFSA is illustrated in Figure 1b; the sulfonic acid group is connected to the perfluoroethereal side chains of the PFSA. Proton conductivity is due to the significant phase separation between hydrophilic and hydrophobic domains in PFSA when hydrated; and the chemical/mechanical stability is caused by the rigid structure of the polytetrafluoroethylene (PTFE) backbone and strong C-F bond even in the side chains. However, this type of membrane exhibited a severe defect at temperatures below zero degrees Celsius and above hundred degrees Celsius [13,14]. Another kind of membrane, Nafion ${ }^{\text {TM }}$, developed and introduced by Dupont in the 1960s, has been extensively studied and is a commercially available proton-conducting membrane in PEMFC applications. Nafion ${ }^{\mathrm{TM}}$ shows excellent characteristics, such as high electrochemical and chemical stability, low permeability to reactant species, selective and high ionic conductivity, and the ability to provide electronic insulation. However, the Nafion ${ }^{\mathrm{TM}}$ membrane showed poor proton conductivity at higher temperatures due to dehydration of water, which controlled the number of water-filled channels [15-17]. To solve these problems, researchers have developed alternative ways of proposing other polymeric materials, such as SPEEK (sulfonated poly(ether ether ketone)) [18,19], polybenzimidazole (SPBI) [20,21], and polysulfone (SPSU or SPSF) [22,23]. These membranes show their strengths in different features of water uptake \%, ionic conductivity, and mechanical and thermal stability. The pictorial illustration of PEMFC is depicted in Figure 2a along with cell reaction.

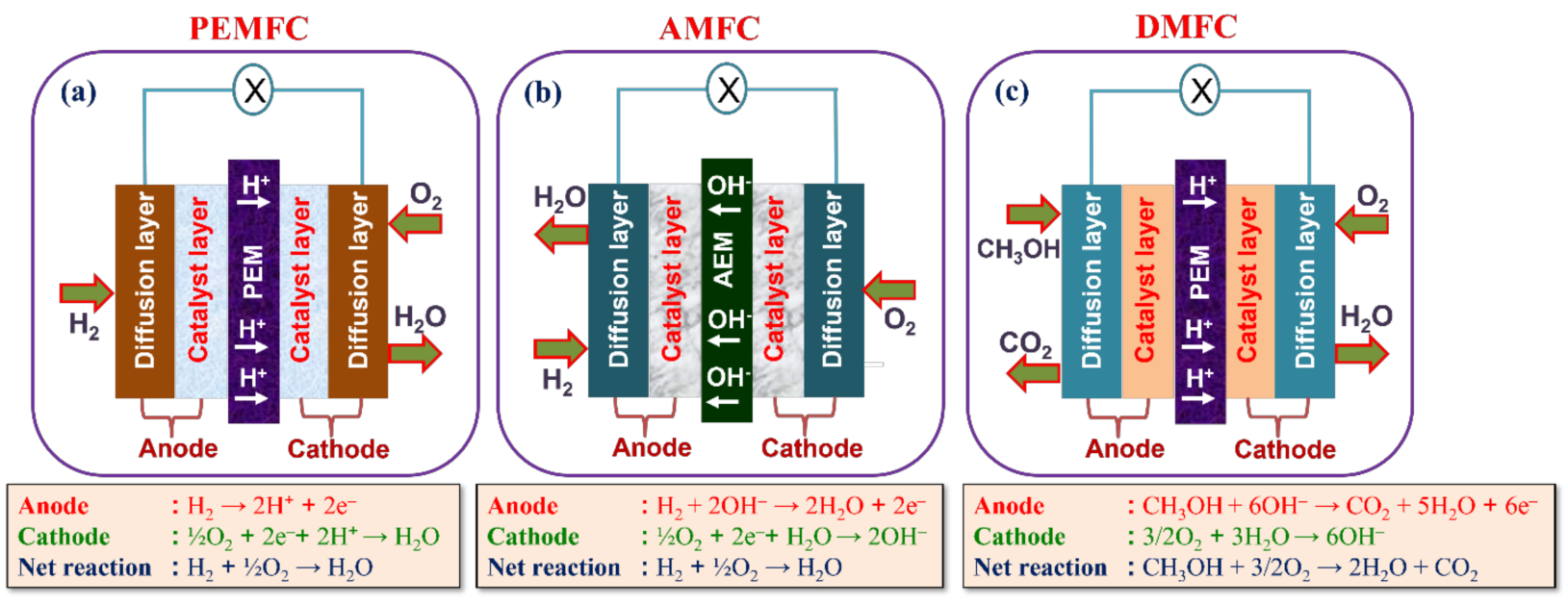

Figure 2. Schematic illustration of (a) PEMFC; (b) AMFC, and (c) DMFC with half-cell reaction.

\subsubsection{DMFCs}

The DMFCs have few merits of efficiently working at low temperature, easy strategy, and eco-friendly characteristics. The usage/handle of methanol is also easy since it exhibits liquid properties at ambient temperature. More specifically, unlike PEMFCs, aqueous methanol-based DMFCs do not require a humidification system and peculiar thermal management aids. They also have superior energy and power density as compared to indirect fuel cells and recently established lithium-ion batteries (LIBs). A plausible usage of the DMFC comprises portable electronic gadgets, military communications, transportation services, and traffic lights/signals [23-25]. The schematic of DMFC is presented in Figure 2c. The major issue with DMFCs is methanol cross-over as it permeates methanol along with water from anode to cathode direction. During DMFC operation, methanol cross-over outcomes in low power-output due to methanol oxidation at the cathode with the aid of cathode catalysts, leading to (i) electrode depolarization, (ii) mixed potential, consequently open-circuit voltage (OCV) of the DMFC less than $0.8 \mathrm{~V}$, (iii) consuming of oxygen, (vi) CO 
poisoning, and $(\mathrm{v})$ severe water accretion at the cathode, which restricts oxygen contact to cathode catalyst spots. In addition, the presence of excessive methanol cross-over lowers the overall performance of the fuel cell [26-28].

\subsubsection{AMFCs}

In principle, $\mathrm{AMFC}$ is a feasible substitute for PEMFC and is currently receiving new consideration. In AMFCs, the AEM conducts $\mathrm{OH}^{-}$(hydroxide) or $\mathrm{CO}_{3}{ }^{2-}$ (carbonate) anions while an electric current is flowing, which has numerous advantages, (i) in a high alkaline environment, both oxygen reduction reaction and methanol oxidation are more predominant; electro-osmotic drag by $\mathrm{OH}^{-}$moves from cathode to anode, which reduces anode to cathode methanol cross-over, simplifies water management, and (ii) allows the use of nonnoble metal catalysts. These AEMs are cheap and have improved mechanical/chemical characteristics compared to PEMs. In recent years, more research attempts have been performed to synthesize novel AEMs to enhance their ionic $\left(\mathrm{OH}^{-}\right)$conductivity [29] along with alkaline stability [30,31]. Polymer back bones such as polystyrene (ethylene butylene) polystyrene [32], poly(2,6-dimethyl-1,4-phenylene oxide) [33], polystyrene [34], poly(ether ether ketone) [35], poly(vinyl alcohol) [36], and polyether sulfone [37,38] have been expansively explored to synthesize alkaline membranes. The afore-mentioned polymeric materials can be readily functionalized with the following cationic groups, quaternary phosphonium [39,40], guanidinium [41,42], quaternary ammonium [43], or imidazolium [44-46] which are accountable for creating the polymer backbone conductive.

\subsection{Ion Exchange Membranes}

For all FCs, the membrane (PEM or AEM) is the heart of the FC. It plays a prominent part in the transportation of ions within a fuel cell via the following aspects: (1) friction through the pore walls, (2) the energy of the membrane swelling process, (3) complete blockage of transport due to insufficient water absorption, (4) hydrophobic/hydrophilic contact between solvation shells and water dipoles, (5) effects of double-layer and (6) surface diffusion $[47,48]$. The main difference between CEMs and AEMs are tabulated in Table 1.

Table 1. Difference between cation and anion exchange membrane.

\begin{tabular}{|c|c|c|}
\hline IEM & CEM & AEM \\
\hline Counter ion & $\mathrm{H}^{+}$conductive & $\mathrm{OH}^{-}$conductive \\
\hline Ion-exchange group & $-\mathrm{SO}_{3}^{-} ;-\mathrm{PO}_{4}^{-} ;-\mathrm{CO}_{2}^{-}$ & $\begin{array}{l}\text { Quaternary ammonium cation, } \\
\text { 1-methyl pyridinium }\end{array}$ \\
\hline Features & $\begin{array}{l}\text { High ionic conductivity, } \\
\text { excellent ionomer solution }\end{array}$ & $\begin{array}{l}\text { Non-noble metal catalyst can be } \\
\text { used. Oxygen reduction reaction } \\
\text { and methanol oxidation reaction are } \\
\text { more facile. }\end{array}$ \\
\hline Issues & $\begin{array}{l}\text { High-cost materials, } \\
\text { fuel crossover, chemical, and } \\
\text { mechanical stability, } \\
\text { practical lifetime }\end{array}$ & $\begin{array}{l}\text { Low ionic conductivity, low } \\
\text { thermostability, influence of } \mathrm{CO}_{2} \text {, } \\
\text { durability, chemical, and } \\
\text { mechanical stability }\end{array}$ \\
\hline
\end{tabular}

\subsection{Preliminary Characteristic of IEM}

The prepared IEMs were subjected to the following preliminary characterization studies: water uptake (WU), ion exchange capacity (IEC), ionic conductivity, permeability of methanol (p), and alkaline stability test to check the appropriateness of the IEMs in FC applications, and the pictorial protocol is illustrated in Figure 3. 


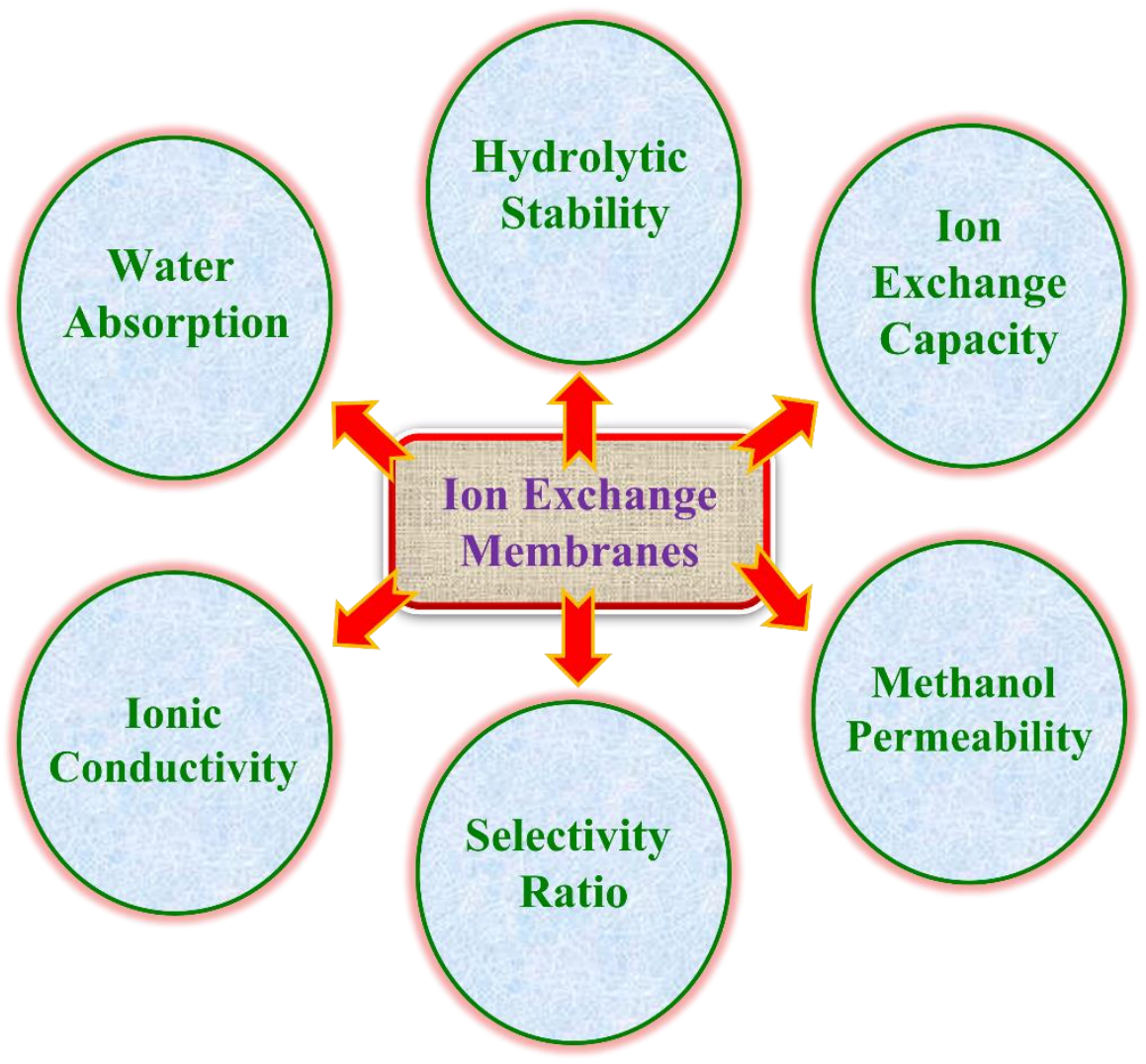

Figure 3. Characteristics of IEMs for FC applications.

\subsubsection{Water Uptake and Schroeder's Paradox}

The WU of the IEM was measured by calculating the weights of the dry and wet membrane samples. The dry membrane weight $\left(\mathrm{W}_{\mathrm{dry}}\right)$ is obtained by drying the sample at $100{ }^{\circ} \mathrm{C}$ for $12 \mathrm{~h}$ immediately before weighing it. The weight of the corresponding membrane in wet conditions $\left(W_{\text {wet }}\right)$ is obtained by immersing the membrane sample in deionized water (DI water) at room temperature for about 1 day, wiping off the surface moisture with filter paper and then quickly weighing it. The water uptake (\%) was determined from the subsequent equation [49]:

$$
\mathrm{WU}(\%)=\frac{\mathrm{W}_{\text {wet }}-\mathrm{W}_{\mathrm{dry}}}{\mathrm{W}_{\mathrm{dry}}} \times 100 \%
$$

In addition, the sorption may be measured by bringing a membrane to equilibrium with a liquid by either immersion of the membrane into the liquid (directly) or by contact with the vapor phase (isopiestically). Since the solution, the vapor, and the sample are all in equilibrium, it is believed that there is no difference between the two methods. The uptake of water by PFSA from a liquid reservoir and a saturated vapor reservoir differs under the same conditions. This phenomenon is called Schroeder's paradox, and more recently, attempts have been made to explain this phenomenon theoretically.

\subsubsection{Ion Exchange Capacity}

IEC is a quantity of the capacity of an insoluble substance to endure ions displacement with formerly attached and lightly encapsulated into its architecture by oppositely charged ions existing in the adjacent solution. IEC was calculated by a back titration method with the following formula [50]:

$$
\text { IEC }\left(\text { meq. }^{-1}\right)=\frac{\text { Titre value } \times \text { Normality of tirant }}{\text { Membrane weight }(\text { dry })}
$$




\subsubsection{Ionic Conductivity}

The ionic conductivity of the IEM was measured by AC impedance spectroscopy. Prior to the testing, the membranes (IEMs) of various forms were fully hydrated overnight in DI water. The measuring device with IEM was positioned in DI water to maintain the relative humidity (RH) at $100 \%$ throughout the experiment. Membrane resistance was measured from the difference in the resistance between the blank cell and the one with IEM separates the counter electrode and working electrode compartment and is converted into ionic conductivity values using the below formula [51]:

$$
\text { Ionic conductivity }\left(\mathrm{S} \mathrm{cm}^{-1}\right)=\frac{\mathrm{L}}{\mathrm{R} \times \mathrm{A}}
$$

where $\mathrm{R}$ is resistance of IEM (ohm); L is width of IEM $(\mathrm{cm})$; A is area of IEM $\left(\mathrm{cm}^{2}\right)$.

\subsubsection{Methanol Permeability}

The methanol permeability ( $p)$ is studied at ambient temperature using a two-portion diffusion cell comprising of a collector $(\mathrm{C})$ and a reservoir $(\mathrm{R})$. $\mathrm{C}$ and $\mathrm{R}$ were separated by the investigated IEM, occupied with DI water, methanol, respectively. Both the portions are stirred continuously during the permeability test. The methanol permeability is calculated from the time versus concentration curve of the methanol collector slope values according to the following equation [52].

$$
\mathrm{p}\left(\mathrm{cm}^{2} \mathrm{~s}^{-1}\right)=\frac{\mathrm{m} \times \mathrm{V}_{\mathrm{C}} \times \mathrm{d}}{\mathrm{A} \times \mathrm{C}_{\mathrm{R}}}
$$

where $\mathrm{m}$ represents the linear plot slope; $\mathrm{V}_{\mathrm{C}}$ signifies the methanol solution volume in the C; A and d illustrate the area and thickness of the IEM; $C_{R}$ is the methanol concentration in the tank.

\subsubsection{Selectivity Ratio}

Especially for DMFCs, the IEM must have two significant characteristics. The proton/hydroxide ionic conductivity should be maximal and have minimal methanol diffusion. Therefore, the higher the ratio of ionic conductivity to methanol permeability (termed as selectivity ratio), the better the IEM performance of the DMFC. This selectivity ratio indicates the performance of the IEM [53].

\subsubsection{Oxidative Stability}

Oxidative resistance is studied by Fenton's test in terms of weight loss over a period. In Fenton's reagent, degradation of the polymer is caused by free radicals attacking the electrophilic sites, leading to weight loss.

\section{Polysulfone}

Polysulfone is a commercially existing aromatic polymer. The relentless attention of the membrane researchers for PSU is because of its outstanding properties [54], such as soluble tendency in a wide range of solvents (dimethylformamide, dimethyl sulfoxide, halogen derivative, dimethyl acetamide, halogen derivatives), excellent film forming capacity, withstanding in high temperatures, wide range of operating $\mathrm{pH}$, outstanding mechanical strength, and reasonable reactivity in aromatic electrophilic substitution reactions (acylation, chloromethylation, nitration, sulfonation, etc.) [55]. The chemical structure of polysulfone is shown in Figure 4. In this present review, we have seen the recent developments of the polysulfone-based membrane and its composites for PEMFCs, DMFCs, and AMFCs applications. 


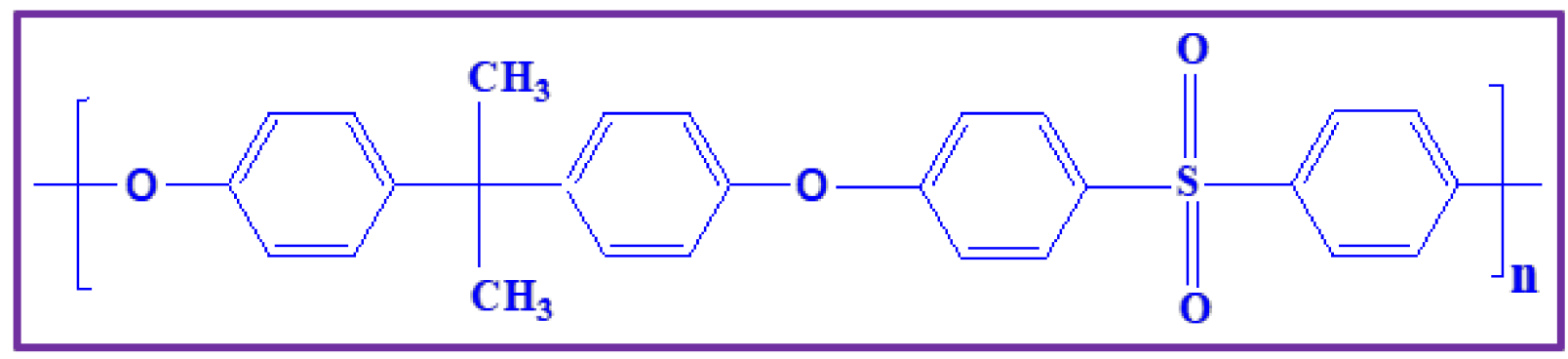

Figure 4. Chemical structure of PSU.

\subsection{Membranes Derived from Polysulfone and Its Composites for PEMFCs Application}

PEMFC technology has evolved quickly over the past 2 decades, with many advantages over traditional energy storage devices, such as batteries and internal combustion engines. PEMFCs are more energy-efficient related with diesel/gas engines. They also produce no hazardous by-products [56-58]. However, the practical feasibility of this technology is highly dependent on the PEM and its characteristics [59,60]. Hence, PEM is a crucial component in PEMFCs devices. The outcome of PEM depends not only on excellent mechanical and thermal resistance but also on the other characteristics, such as film-forming capacity, excellent proton conductivity, and reduced methanol cross-over [61,62]. Recently, nano fillers have been widely explored to adjust polymeric membranes to enhance the outcome of PEMs. These enhancements are reached by introducing a nonstop proton transfer path in the polymer environment and enhanced mechanical/ thermal characteristics of the polymer $[63,64]$

Metal-organic frameworks (MOFs) as carriers for proton-conducting material have received remarkable attraction from many experimental scientists owing to their high surface area compared to usual filler materials that permits encapsulation of proton transfer material [65,66]. For example, Leila Ahmadian-Alam and Hossein Mahdavi reported a ternary composite membrane composed of MOF and sulfonic acid functionalized silica $\left(\mathrm{MOF} / \mathrm{SO}_{3} \mathrm{H}-f-\mathrm{Si}\right)$ nanoparticles with polysulfone for PEMFCs [67]. The implanting of $\mathrm{MOF} / \mathrm{SO}_{3} \mathrm{H}-f$-Si nanoparticles on sulfonated PSU ensued in substantial enhancement of the thermal and mechanical properties of the composite membrane. The ion conductivity and transport properties of the composite membrane were increased to $0.017 \mathrm{~S} \mathrm{~cm}^{-1}$ by adding only $5 \%$ of $\mathrm{MOF} / \mathrm{SO}_{3} \mathrm{H}-f$-Si nanoparticles. Furthermore, the nanocomposite exhibited a supreme power density (PD) of $40.80 \mathrm{~mW} \mathrm{~cm}^{-2}$. Nor Azureen Mohamad et al. described cross-linked highly sulfonated polyphenylene sulfone (SPPSU) membranes comprised of carbon nanodots (CNDs) as a PEM for PEMFCs application [68]. The cross-linked membrane was prepared by pyrolysis at $453 \mathrm{~K}$, where cross-linking occurs between SPPSU and CNDs. The prepared cross-linked composite membrane showed the maximum ionic conductivity of $56.3 \mathrm{mS} \mathrm{cm}^{-1}$. Further, the authors demonstrated that the CNDs encapsulation into SPPSU membrane by pyrolysis treatment displayed a high ionic conductivity with superior dimensional stability. Recently, Balappa B. Munavalli and Mahadevappa Y. Kariduraganavar have prepared PEM based composite membrane by two step methods. First, sulfanilic acid $\left(\mathrm{H}_{2} \mathrm{~N}-\mathrm{C}_{6} \mathrm{H}_{4}-\mathrm{SO}_{3} \mathrm{H}\right)$ functionalized poly $(1,4$-phenylene ether ether sulfone) (SPEESSA) was synthesized. Then, different weight percentages of $-\mathrm{SO}_{3} \mathrm{H}$ functionalized zeolites have been incorporated into the prepared composite membrane [69]. The composite membranes, Na-ZSM- 5 zeolite, Na- $\beta$ zeolite, and Na-Mordenite zeolite, exhibited the ionic conductivities of 102,112 , and $124 \mathrm{mS} \mathrm{cm}^{-1}$, respectively. Furthermore, the composite membrane with 8 weight $\%$ Na-ZSM-5 zeolite, Na-Beta zeolite, and NaMordenite zeolite exhibited outstanding PD of $0.37,2.042$, and $0.45 \mathrm{~W} \mathrm{~cm}^{-2}$, respectively, in $\mathrm{H}_{2} / \mathrm{O}_{2}$ fuel cells. In addition, the obtained PEMFCs results were much better than the commercially existing Nafion ${ }^{\circledR} 117$ membranes. Jinzhao Li et al. reported graphene oxide-based nanoscale ionic materials (NIMs-GO) by sulfonation with 3-(trihydroxysilyl)1-propanesulfonic acid (SIT) and consequent neutralization with amino-terminated poly- 
oxypropylene (PO)-polyoxyethylene (EO) block co-polymer [70]. The schematic illustration of the NIMs-GO synthesis is depicted in Figure 5(A1). Transmission electron microscopy (TEM) was employed to analyze the morphology of the prepared GO, SIT-GO, and NIMsGO (Figure 5a-f). Despite sulfonation by SIT, GO nanosheets exhibit a wrinkled and folded configuration, an intrinsic property of GO due to their large surface area and intramolecular attraction. Remarkably, the NIMs-GO exhibited greatly stretched features (Figure 5e,f), after being ion-exchanged with M2070. The authors stated that the change in morphology confirms that the M2070 has been ionically bonded to the GO surface via $-\mathrm{SO}_{3} \mathrm{H} /-\mathrm{NH}_{2}$ interactions. The resulting NIMs-GO with acid-base pairs and hygroscopic EO units were incorporated into sulfonated polysulfone (SPSF) to fabricate nanocomposite membranes. The water uptake and retention ability of the SPSF/NIMs-GO nanocomposite membranes were enhanced due to the hydrophilic EO units of NIMs-GO. Furthermore, the maximum PD of $167.6 \mathrm{~mW} \mathrm{~cm}^{-2}$ was attained for SPSF/NIMs-GO-3 at $60{ }^{\circ} \mathrm{C} / 100 \% \mathrm{RH}$, which is higher than that of Nafion ${ }^{\circledR} 117$ and the pristine SPSF membrane (Figure 5(B1)). When the relative humidity drops to $50 \%$ (Figure 5(B2)), the maximum PD of $33.3,17$, and $23.2 \%$ decreases by SPSF, SPSF/NIMs-GO-3, and Nafion ${ }^{\circledR} 117$, respectively. All these results are due to the increased $\mathrm{H}^{+}$conductivity of the fuel cell in both hydrated and low relative humidity conditions.
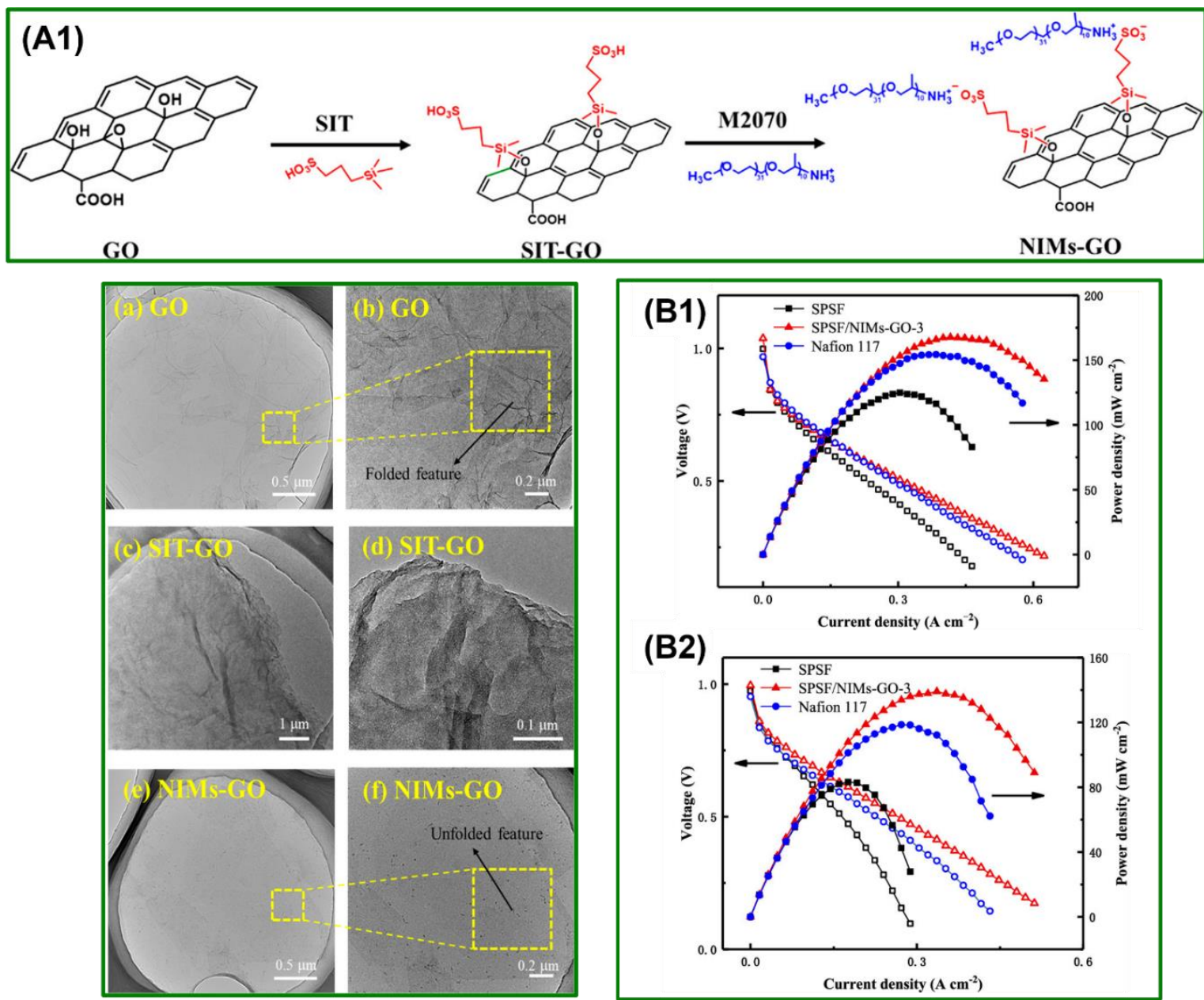

Figure 5. (A1) Reaction protocol of SIT-GO and NIMs-GO; (a-f) represents the TEM images of the prepared GOs; $\mathrm{H}_{2} / \mathrm{O}_{2}$ fuel cell performances at (B1) $60{ }^{\circ} \mathrm{C} / 100 \% \mathrm{RH}$ and (B2) $60{ }^{\circ} \mathrm{C} / 50 \% \mathrm{RH}$. Reproduced with permission from [70]. Copyright 2019 American Chemical Society.

Recently, Cataldo Simari et al. synthesized sulfonated polysulfone (SPSF)/layered double hydroxide $(\mathrm{LDH})$ nanocomposite membranes with various weight percentage 
filler content by an easiest solution intercalation method to replace Nafion ${ }^{\circledR}$ electrolyte in PEMFCs applications [71]. The comprehensive exfoliation and nano dispersion of the LDH platelets into the polymer improve the thermomechanical resistance, water retention capability, and dimensional stability of the electrolyte membranes. The photographic images of the prepared PEMs were depicted in Figure 6a. All membranes except the sPSU$\mathrm{LDH}_{4}$ membrane are transparent. In addition, no inorganic particles are noticed in both the sPSU- $\mathrm{LDH}_{2}$ and sPSU-LDH $\mathrm{LH}_{3}$ membranes illustrating no agglomeration. The power density and polarization curves are shown in Figure 6b,c. The maximum PD of $204.5 \mathrm{~mW} \mathrm{~cm} \mathrm{~cm}^{-2}$ at $110{ }^{\circ} \mathrm{C} / 25 \% \mathrm{RH}$ was achieved for the sPSU-LDH $\mathrm{LD}_{3}$ composite membrane, which is double the value achieved by the Nafion ${ }^{\circledR}$ membrane. Such a superficial performance was attributed by the establishment of extremely interconnected ion pathways encouraging an efficient Ghrotthus-type mechanism for the $\mathrm{H}^{+}$passage even in dehydrated environments.

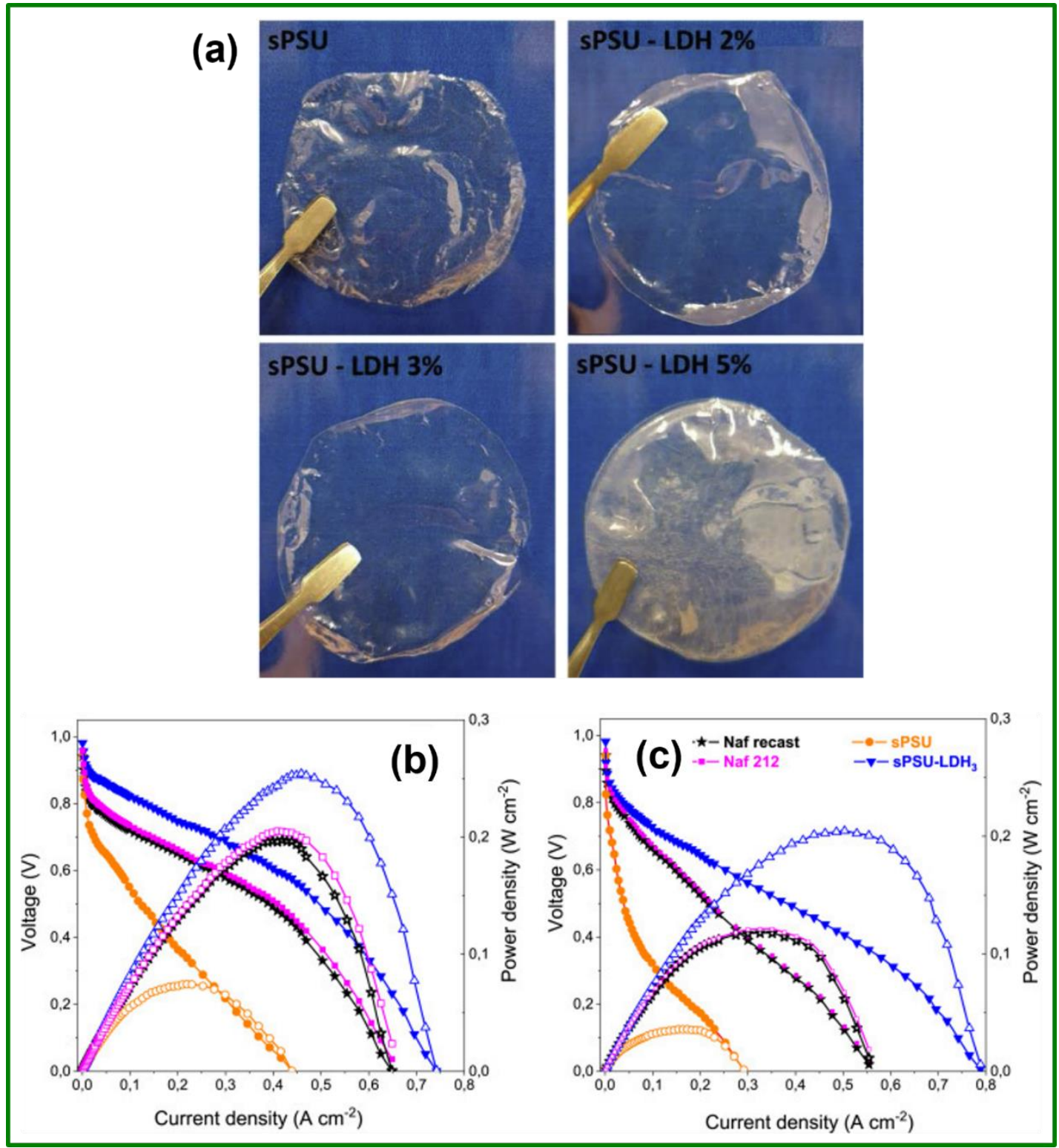

Figure 6. (a) Pictorial representation of the prepared membranes; cell voltage and PD plots of $\mathrm{H}_{2} / \mathrm{O}_{2}$ fuel cell at (b) $80{ }^{\circ} \mathrm{C} / 30 \% \mathrm{RH}$ and (c) $110{ }^{\circ} \mathrm{C} / 25 \% \mathrm{RH}$. Reproduced with permission from [71]. Copyright 2020 Elsevier. 
Ting Pan et al. described novel composite membrane from functionalized PSU with high sulfonic acid groups, N,N-bis (sulfopropyl)aminyl-4-phenyl polysulfone (PSF-N$\mathrm{C}_{3} \mathrm{H}_{6} \mathrm{SO}_{3} \mathrm{H}$ ) and $\mathrm{O}, \mathrm{O}^{\prime}$-bis(sulfopropyl)resorcinol-5-yl-4-phenyl polysulfone (PSF-O$\left.\mathrm{C}_{3} \mathrm{H}_{6} \mathrm{SO}_{3} \mathrm{H}\right)$ [72]. The above polymers prepared by grafting amino phenyl group and dimethoxy phenyl groups to the polymer backbone through bromination of PSU followed by Suzuki cross-coupling reaction, and the introduction of the sulfopropyl groups through sulfone ring-opening reaction. Furthermore, the prepared composite membrane exhibited the highest proton conductivity of $46.66 \mathrm{mS} \mathrm{cm}^{-1}$ at $95^{\circ} \mathrm{C} / 90 \% \mathrm{RH}$. In addition, the prepared membrane exhibited an adequate swelling ratio and water uptake and reduced methanol cross-over. The outstanding presentation of the composite membrane is due to the phase separation between the hydrophobic and hydrophilic subphases and the establishment of the hydrogen-bonding network in the hydrophilic subphase. Very recently, Berlina Maria Mahimai et al. prepared a series of nanocomposites from PSF, SPANI (sulfonated polyaniline), and $\mathrm{Nb}_{2} \mathrm{O}_{5}$ (niobium pentoxide) by the solution casting method [73]. The composite membrane with $10 \mathrm{wt} \% \mathrm{Nb}_{2} \mathrm{O}_{5} / \mathrm{PSF} / \mathrm{SPANI}$ displayed the highest ionic conductivity of $0.0674 \mathrm{~S} \mathrm{~cm}^{-1}$. Furthermore, the authors demonstrated that incorporating $\mathrm{Nb}_{2} \mathrm{O}_{5}$ into virgin PSF enhanced the proton conductivity and improved the thermal and oxidative stability.

In order to find different polymer electrolyte materials other than $\mathrm{Nafion}^{\mathrm{TM}}$, polymeric membranes functionalized with $\mathrm{H}_{3} \mathrm{PO}_{3}$ (phosphonic acid) groups have encouraged much research consideration owing to their enhanced ionic conductivity at high temperature under dehydration environment ascribing to the self-ionization of $\mathrm{H}_{3} \mathrm{PO}_{3}$ groups within an infused hydrogen-bonding network [74,75]. When compared with $\mathrm{SO}_{3} \mathrm{H}$ and $\mathrm{COOH}$, the $\mathrm{H}_{3} \mathrm{PO}_{3}$ group has moderate acidity and low water solubility and swelling ability, so it has a high ability for hydrogen bonding [76]. Furthermore, the bond that exists in phosphonic acid (-C-P-) is more thermally and electrochemically stable than the sulfonic acid (-C-S-) bond and carboxylic acid (-C-C-) bond, and therefore, more appropriate for PEMFCs application [77,78]. For example, Lesi Yu et al. reported proton-conducting composite membrane from SPSF and polysulfone grafted (phosphonated polystyrene) (SPSF/PPSF) through controlled atom transfer radical polymerization (ATRP) for PEMFCs application [79]. The supreme ionic conductivity of $0.01723 \mathrm{~S} \mathrm{~cm}^{-1}$ at $95^{\circ} \mathrm{C} / 90 \% \mathrm{RH}$ was achieved. Furthermore, the SPSF/PPSF membrane exhibited promising thermal stability, adequate swelling ratio, and water uptake, notably enhanced mechanical stability. In addition, the permeability of methanol decreased from $5.74 \times 10^{-8} \mathrm{~cm}^{2} \mathrm{~s}^{-1}$ for PPSF to $0.96 \times 10^{-8} \mathrm{~cm}^{2} \mathrm{~s}^{-1}$ for the composite membrane.

PEMFCs operating at high temperatures (HT-PEMFCs) have received considerable attraction owing to their improved electrode reaction kinetics and simplified humidification and thermal management $[80,81]$. In the HT-PEMFC devices, the PEM is a vital element for carrying $\mathrm{H}^{+}$(protons) and allocating fuel and oxygen. Hence, HT-PEMs necessitate both good ionic conductivity and adequate mechanical stability. There have been incredible efforts to progress HT-PEMs with high proton transport capacity at higher temperatures (120-300 ${ }^{\circ} \mathrm{C}$ ). Recently, Hongying Tang et al. have prepared phosphate poly(phenylene sulfone) (P-PPSU) by post-phosphonylation of brominated poly(phenylene sulfone) (BrPPSU), followed by acidification [82]. In addition, the prepared P-PPSU material can act as a binder material in the catalyst layer to decrease the decay of operating performance of HT-PEMFC operations. The ionic conductivity of P-PPSU membrane at a high temperature without extra humidification is only $0.30 \mathrm{mS} \mathrm{cm}^{-1}$ at $160{ }^{\circ} \mathrm{C}$, the PD of $242 \mathrm{~mW} \mathrm{~cm}^{-2}$ is attained in fuel cell operation at $160{ }^{\circ} \mathrm{C}$. The obtained values are low when compared with Nafion binder material; however, the excellent stability of $200 \mathrm{~h}$ is noticed in FCs worked at $160^{\circ} \mathrm{C}$ with P-PPSU polymer binder with no noteworthy decrease in the fuel cell evaluation. Hence, the authors demonstrated that the prepared P-PSSU is a viable candidate as a binder material in the catalyst layer for extremely robust HT-PEMFCs. Jujia Zhang et al. have also prepared 2,4,6-tri(dimethylaminomethyl)-phenol (TDAP) with three tertiary amine groups that were grafted to PSF (TDAP-PSF) to attain higher phosphoric acid uptake at 
lower grafting degree from HT-PEMFCs [83]. Furthermore, the single cell reaches the PD of $453 \mathrm{~mW} \mathrm{~cm}^{-2}$ and has excellent stability without exterior humidification. Huijuan Bai et al. also described a new strategy for grafting poly(1-vinylimidazole) with phosphoric acid doping sites on the PSF backbone via ATRP [84]. The authors demonstrated that the high $\mathrm{H}^{+}$conductivity is attained due to the establishment of micro-phase separated structures, and mechanical properties are maintained due to the decreased plasticizing effect produced by the separation of phosphoric acid adsorption sites and the polymer backbone. The obtained phosphoric acid incorporated membranes have outstanding ionic conductivity of $127 \mathrm{mS} \mathrm{cm}^{-1}$ at $160{ }^{\circ} \mathrm{C}$ and excellent tensile strength of $7.94 \mathrm{MPa}$. On the other hand, the single $\mathrm{H}_{2} / \mathrm{O}_{2}$ fuel cell performance with the optimized membrane is inspiring, achieving a peak PD of $559 \mathrm{~mW} \mathrm{~cm}^{-2}$ at $160{ }^{\circ} \mathrm{C}$. Table 2 summarized the preliminary characteristics of various proton-conducting polysulfone-based composite membranes along with their fuel cell evaluations.

Table 2. Preliminary characteristics of various proton-conducting polysulfone based composite membranes along with their fuel cell evaluation.

\begin{tabular}{|c|c|c|c|c|c|c|c|c|}
\hline \multirow[b]{2}{*}{ Membrane } & \multicolumn{6}{|c|}{ Membrane Characteristics } & \multirow[b]{2}{*}{$\begin{array}{c}\text { Fuel Cell } \\
\text { Performance }\end{array}$} & \multirow[b]{2}{*}{ Ref } \\
\hline & WA $(\%)$ & $\begin{array}{c}\text { IEC } \\
\text { (meq. } \mathrm{g}^{-1} \text { ) }\end{array}$ & $\begin{array}{c}\text { Ionic } \\
\text { Conductivity } \\
\left(\mathrm{S} \mathrm{cm}^{-1}\right)\end{array}$ & $\begin{array}{c}\text { Methanol } \\
\text { Permeability }\end{array}$ & $\begin{array}{l}\text { Selectivity } \\
\text { Ratio }\end{array}$ & $\begin{array}{l}\text { Oxidative } \\
\text { Stability }\end{array}$ & & \\
\hline $\begin{array}{l}\mathrm{PSF} / \mathrm{MOF} / \mathrm{Si} \\
\text { nanocomposite }\end{array}$ & 16.50 & 0.86 & $0.017 @ 70^{\circ} \mathrm{C}$ & - & - & - & $\begin{array}{c}\text { OCV: } 0.90 \mathrm{~V} ; \mathrm{PD}: \\
40.80 \mathrm{~mW} \mathrm{~cm}^{-2} @ \\
160^{\circ} \mathrm{C}\end{array}$ & [67] \\
\hline $\begin{array}{l}\text { Crosslinked } \\
\text { CNDs-SPPSU }\end{array}$ & 134 & 1.67 & $0.0563 @ 80^{\circ} \mathrm{C}$ & - & - & - & $\begin{array}{c}\text { OCV: } 1.0224 \mathrm{~V} @ \\
100 \% \mathrm{RH}\end{array}$ & [68] \\
\hline $\begin{array}{l}\text { SPEESSA/sulfonic } \\
\text { acid zeolite } \\
\text { composite }\end{array}$ & 29.12 & 3.189 & 0.124 & - & - & - & $\begin{array}{c}\text { OCV: } 0.91 \mathrm{~V} ; \text { PD: } \\
0.45 \mathrm{~W} \mathrm{~cm}^{-2} @ \\
1.1 \mathrm{~A} \mathrm{~cm}^{-2}\end{array}$ & [69] \\
\hline $\begin{array}{l}\text { SPSU /NIMs-GO } \\
\text { composite }\end{array}$ & 34.1 & 1.49 & $0.23 @ 75^{\circ} \mathrm{C}$ & - & - & - & $\begin{array}{l}\text { OCV: } 1.038 \mathrm{~V} \text {; PD: } \\
167.6 \mathrm{~mW} \mathrm{~cm}^{-2} @ \\
60^{\circ} \mathrm{C}\end{array}$ & {$[70]$} \\
\hline $\begin{array}{l}\text { SPSU-LDH } \\
\text { composite }\end{array}$ & 31 & 1.49 & $0.0137 @ 120^{\circ} \mathrm{C}$ & - & - & - & $\begin{array}{c}\text { PD: } \\
204.5 \mathrm{~mW} \mathrm{~cm}{ }^{-2} @ \\
110^{\circ} \mathrm{C}\end{array}$ & [71] \\
\hline $\begin{array}{l}\text { PSF-N- } \mathrm{C}_{3} \mathrm{H}_{6} \mathrm{SO}_{3} \mathrm{H} / \\
\text { PSF-O- } \mathrm{C}_{3} \mathrm{H}_{6} \mathrm{SO}_{3} \mathrm{H}\end{array}$ & 60 & 2.03 & 0.04666 & $2.65 \times 10^{-8} \mathrm{~cm}^{2} \mathrm{~s}^{-1}$ & - & $\begin{array}{l}94.12 \% \text { residual } \\
\text { mass remains at } \\
80^{\circ} \mathrm{C} \text { for } 1 \mathrm{~h} \text { in } \\
\text { Fenton's solution }\end{array}$ & - & [72] \\
\hline $\begin{array}{c}\mathrm{PSU} / \mathrm{SPANI} / \mathrm{Nb}_{2} \mathrm{O}_{5} \\
\text { nanocomposite }\end{array}$ & 17.6 & 1.50 & 0.0674 & - & - & $\begin{array}{l}98.6 \% \text { residual } \\
\text { mass remains in } \\
\text { Fenton's solution }\end{array}$ & - & [73] \\
\hline $\begin{array}{c}\text { PSU-g- } \\
\text { phosphonated } \\
\text { polystyrene/SPSU } \\
\text { composite }\end{array}$ & 23.07 & - & $0.0172 @ 95^{\circ} \mathrm{C}$ & $0.96 \times 10^{-8} \mathrm{~cm}^{2} \mathrm{~s}^{-1}$ & - & $\begin{array}{c}>95 \% \text { residual } \\
\text { mass remains at } \\
25{ }^{\circ} \mathrm{C} \text { for } 120 \mathrm{~h} \text { in } \\
\text { Fenton's solution }\end{array}$ & - & [79] \\
\hline Phosphonated PSU & 6.6 & 2.75 & $0.0003 @ 160^{\circ} \mathrm{C}$ & - & - & $\begin{array}{l}87.7 \% \text { residual } \\
\text { mass remains for } \\
70 \mathrm{~h} \text { in Fenton's } \\
\text { solution }\end{array}$ & - & [82] \\
\hline $\begin{array}{c}\text { PA doped } \\
\text { TDAP-g-PSU }\end{array}$ & - & - & $0.056 @ 160^{\circ} \mathrm{C}$ & - & - & - & $\begin{array}{l}\text { OCV: } 0.92 \mathrm{~V} \text {; PD: } \\
453 \mathrm{~mW} \mathrm{~cm}-2 @ \\
150{ }^{\circ} \mathrm{C}\end{array}$ & [83] \\
\hline $\begin{array}{c}\text { Poly(1- } \\
\text { vinylimidazole)-g- } \\
\text { PSU }\end{array}$ & 220.3 & - & $0.127 @ 160^{\circ} \mathrm{C}$ & - & - & - & $\begin{array}{l}\text { OCV: } 0.98 \mathrm{~V} \text {; PD: } \\
559 \mathrm{~mW} \mathrm{~cm}-2 @ \\
160{ }^{\circ} \mathrm{C}\end{array}$ & [84] \\
\hline
\end{tabular}

In summary, the potential of sulfonated polysulfone and its composites, phosphonated polysulfone, and several grafted polymers of sulfonated polysulfone for low and high-temperature polymer electrolyte membranes for PEMFC has been discussed. In general, the incorporation of nano sized inorganic filler or metal organic frameworks or 
zeolites has enhanced a phenomenal result in both the mechanical characteristics and ion conducting properties.

\subsection{Polysulfone and Its Composites for DMFCs}

DMFCs provide numerous distinct advantages associated with reasonable working temperatures, easy handling and storage of liquid fuel (methanol), offering power in the utmost effective way. Furthermore, there is no need to recharge the DMFC because liquid fuel can be delivered directly to the anode, and electricity can be produced immediately. Significantly, it might be the major energy basis for portable electronic instruments and automobiles with no toxic gases associated with combustion engines [85-87]. Sulfonated polysulfone (SPSU) exhibited exceptional mechanical strength and extraordinary methanol resistance (even at $100 \%$ sulfonation), illustrating its tremendous potential for the fabrication of novel polymeric membranes used in DMFC technology. Nevertheless, the very low ionic conductivity of SPSU still remains one of the most serious drawbacks. A favorable and cost-effective method to report this issue is to: (i) blend SPSU with other polymers. In practice, this approach is commonly applied in order to modify the characteristics of a virgin macromolecule, attaining superior properties in the resulting blended materials [88-91]. (ii) The preparation of composite membranes by dispersion of inorganic fillers including silica (SiO2) [92], titania (TiO2) [93], zeolites [94], and heteropoly acids inside the polymer matrix have been demonstrated to satisfactorily enhance the ionic conductivity of the resulting electrolyte without sacrificing its mechanical resistance $[95,96]$; and (iii) the introduction of functionalized 2D-layered materials (example, graphene oxide, smectite clay, layered double hydroxides (LDHs), and siliceous layered materials) effectively lowers the methanol permeability in Nafion-based membranes and simultaneously improves their proton conductivity, water retention capacity, and thermo-mechanical resistance [97-100]. Among these inorganic fillers, LDHs have recently gained more attention, a class of nanostructured materials belonging to the anionic clay family, with unique physicochemical properties [101-104]. For instance, E. Lufrano et al. described the incorporation of hygroscopic LDH particles into SPSU for DMFCs [105]. The substantial enhancement in the water and methanol absorption and dimensional stability of the SPSU/LDH composite membrane was observed when compared with both pristine SPSU and Nafion ${ }^{\circledR}$ 212 membranes. Furthermore, the fabricated single DMFC achieved the remarkable PD of $150 \mathrm{~mW} \mathrm{~cm}^{-2}$ at $80^{\circ} \mathrm{C}$ at higher methanol concentration (5 M methanol) solution. Xianlin $\mathrm{Xu}$ et al. reported bio-inspired amino acid-functionalized cellulose whiskers impregnated SPSU as PEM for DMFCs [106]. The maximum ionic conductivity of $0.234 \mathrm{~S} \mathrm{~cm}^{-1}$ at $80^{\circ} \mathrm{C}$ achieved for $10 \mathrm{wt} \%$ L-Serine-functionalized cellulose whiskers. In addition, enhanced water uptake and reduced methanol cross-over were observed. Therefore, the composition of filler and mixed matrix display outstanding characteristics, and $\mathrm{H}^{+}$conducting mixed-matrix membranes are promising materials in DMFCs. Adnan Ozden et al. prepared SPSU / zirconium hydrogen phosphate (ZrP) composite membranes with different degrees of sulfonation $(20,35$, and $42 \%)$ and a uniform weight percentage of $\mathrm{ZrP}(2.5 \%)$ to alleviate the practical tasks related to the usage of traditional Nafion ${ }^{\circledR}$ membranes in DMFCs [107]. The SPSU / ZrP-42 composite membrane exhibited a maximum OCV of $0.75 \mathrm{~V}$ and PD of $119 \mathrm{~mW} \mathrm{~cm}{ }^{-2}$ at $80^{\circ} \mathrm{C}$. Nattinee Krathumkhet et al. synthesized composite membrane from sulfonated ZSM-5 zeolite and SPSU by solution casting method [108]. First, sulfonated ZSM-5 zeolite was synthesized by an organo-functionalization method using poly(2-acrylamido-2-methylpropanesulfonic acid). Then, SPSU was prepared by the conventional method. The composite membrane, ZSM-5/SPSU, significantly enhanced the ionic conductivity, water uptake, methanol cross-over, and IEC relative to the pristine SPSU membrane. Recently, C. Simari et al. reported blended electrolyte membranes comprised of SPSU and SPEEK (SPSU/SPEEK) with two different ratios, 50/50 and 25/75, through a facile and modest solution casting method for DMFC applications [109]. The fabricated blend membrane showed enhancement of the proton transport along with the reduced methanol cross-over which is one of the essential criteria for DMFC operation. Furthermore, 
the DMFC performance with 25/75 blend membrane showed a PD of $130 \mathrm{~mW} \mathrm{~cm}^{-2}$ at $353 \mathrm{~K}$ in $4 \mathrm{M}$ methanol. Faizah Altaf et al. also prepared sulfonated polysulfone (SPSU) based composite PEM filled with polydopamine (PD) anchored carbon nanotubes (PDCNTs) by phase inversion methodology with varying the filler (PCSPSU) [110] and the detailed reaction protocol was given in Figure 7 . The composite membrane, 0.5 weight $\%$ PDCNTs, displayed a $43 \%$ rise in ionic conductivity compared to the original SPSU membrane, increasing from $0.085 \mathrm{~S} \mathrm{~cm}^{-1}$ for pristine to $0.1216 \mathrm{~S} \mathrm{~cm}^{-1}$ for the composite membrane at $80{ }^{\circ} \mathrm{C}$. The prepared composite membrane also exhibited a remarkable $75 \%$ reduction in methanol permeability $\left(5.68 \times 10^{-7} \mathrm{~cm}^{2} \mathrm{~s}^{-1}\right)$ compared to recast Nafion ${ }^{\circledR} 117$ membranes $\left(23.00 \times 10^{-7} \mathrm{~cm}^{2} \mathrm{~s}^{-1}\right)$. The obtained outcomes suggested that the PD functionalized CNTs based PEMs as a potential candidate for DMFCs.

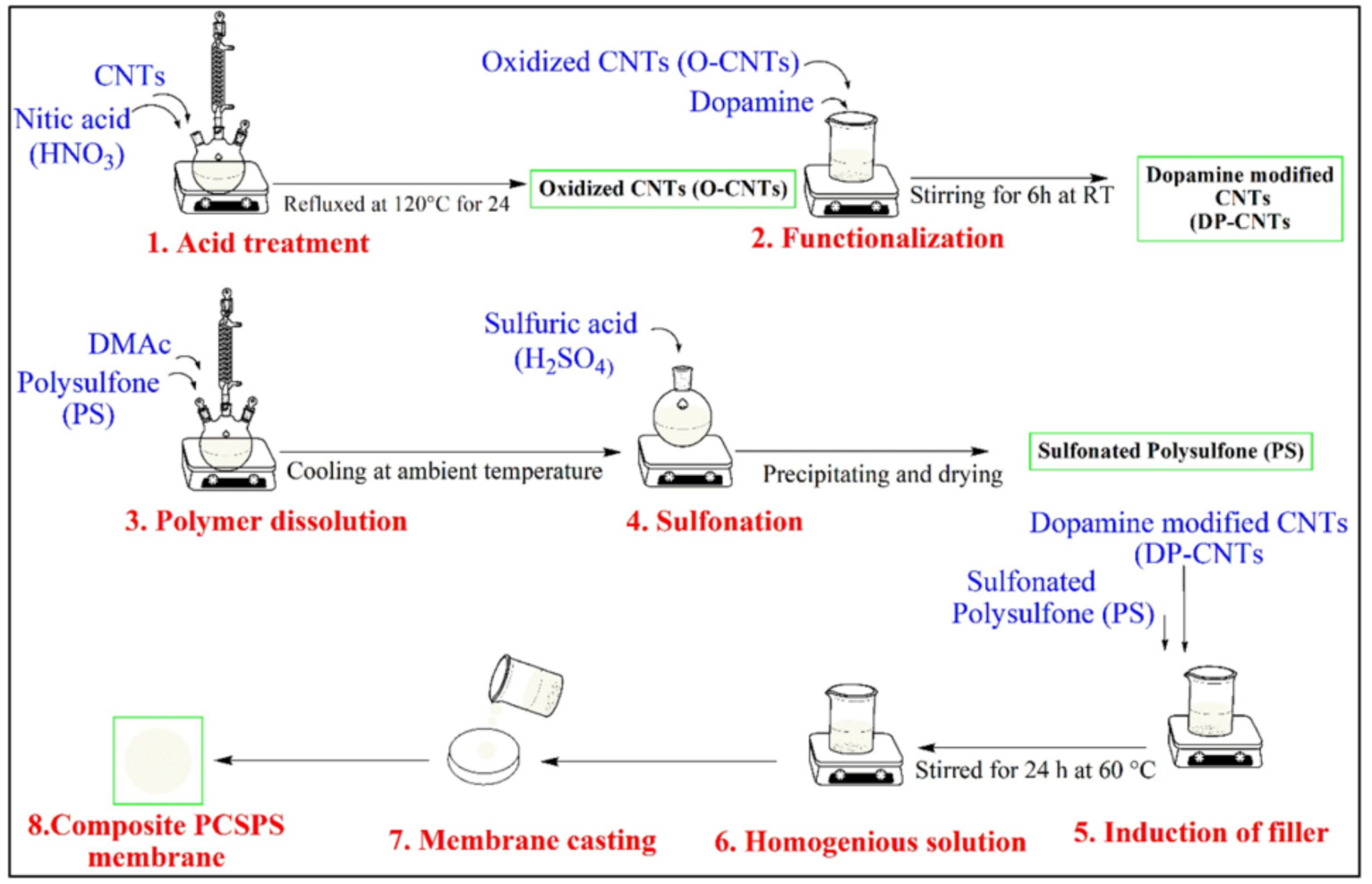

Figure 7. Reaction protocols entailed in the preparation of composite membrane, PCSPSU. Reproduced with permission from [110]. Copyright 2020 Elsevier.

In summary, SPSU membranes-based composite membranes were widely used as PEM for DMFCs to enhance its ionic conductivity, methanol cross-over, and single cell performance. Nevertheless, as previously discussed, in the performances of SPSU composites, blends, and LDH based SPSUs, many inconsistencies with the experimental results in relation to ionic conductivity, water uptake, and so on are perceptible. Each method used to improve the performance of composite and or blend SPSU based membranes offers benefits and drawbacks. Table 3 consists of SPSU and its composites for DMFCs application. 
Table 3. Sulfonate polysulfone and its composites for DMFCs.

\begin{tabular}{|c|c|c|c|c|c|c|c|c|}
\hline \multirow[b]{2}{*}{ Membrane } & \multicolumn{6}{|c|}{ Membrane Characteristics } & \multirow[b]{2}{*}{$\begin{array}{c}\text { Fuel Cell } \\
\text { Performance }\end{array}$} & \multirow[b]{2}{*}{ Ref. } \\
\hline & WA $(\%)$ & $\begin{array}{c}\text { IEC } \\
\left(\text { meq.g }^{-1}\right)\end{array}$ & $\begin{array}{c}\text { Ionic } \\
\text { Conductivity } \\
\left(\mathrm{S} \mathrm{cm}^{-1}\right)\end{array}$ & $\begin{array}{c}\text { Methanol } \\
\text { Permeability } \\
\left(\mathrm{cm}^{2} \mathrm{~s}^{-1}\right)\end{array}$ & $\begin{array}{l}\text { Selectivity } \\
\text { Ratio } \\
\left(\mathrm{sS} \mathrm{cm}^{-3}\right)\end{array}$ & $\begin{array}{l}\text { Oxidative } \\
\text { Stability }\end{array}$ & & \\
\hline $\begin{array}{c}\text { SPSU/LDH } \\
\text { nanocomposite }\end{array}$ & 29 & 1.49 & $0.102 @ 120{ }^{\circ} \mathrm{C}$ & $116 \mathrm{~mA} \mathrm{~cm}^{-2}$ & - & - & 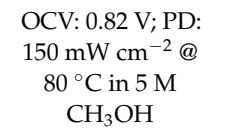 & [105] \\
\hline $\begin{array}{c}\text { Amino-acid } \\
\text { functionalized } \\
\text { cellulose } \\
\text { whiskers/SPSU }\end{array}$ & 68 & - & $0.234 @ 80{ }^{\circ} \mathrm{C}$ & $7.6 \times 10^{-7}$ & - & - & $\begin{array}{c}\text { OCV: } 0.73 \mathrm{~V} \text {; PD: } \\
73.757 \mathrm{~mW} \mathrm{~cm}{ }^{-2} @ \\
60^{\circ} \mathrm{C} \text { in } 2 \mathrm{M} \\
\mathrm{CH}_{3} \mathrm{OH}\end{array}$ & [106] \\
\hline $\mathrm{SPSU} / \mathrm{ZrP}$ & 38 & - & $0.156 @ 80{ }^{\circ} \mathrm{C}$ & - & - & $\begin{array}{l}96.66 \% \text { of } \\
\text { weight } \\
\text { retention after } \\
\text { Fenton test }\end{array}$ & 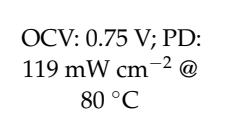 & [107] \\
\hline $\begin{array}{c}\text { Sulfonated } \\
\text { ZSM-5/SPSU }\end{array}$ & 45.41 & 1.03 & $0.00965 @ \mathrm{RT}$ & $2.24 \times 10^{-6}$ & 4309.03 & - & - & [108] \\
\hline SPSU/SPEEK & 34 & - & $0.073 @ 120^{\circ} \mathrm{C}$ & - & - & - & 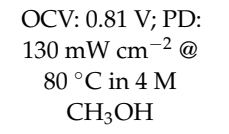 & [109] \\
\hline $\begin{array}{c}\text { PD-CNT/SPSU } \\
\text { composite }\end{array}$ & 32 & - & $0.1216 @ 80^{\circ} \mathrm{C}$ & $5.68 \times 10^{-7}$ & - & - & - & [110] \\
\hline
\end{tabular}

\subsection{Alkaline Based Polysulfone and Its Composites for AMFCs}

Recently, the progress of AMFCs has improved significantly, primarily due to the advantages of the existence of these systems over the widely known PEMFCs. The alkaline medium produced by AEM in the fuel cell favors electrode kinetics [111] and subsequently avoids the usage of expensive and noble metal catalysts. Hence, it is possible to use nonprecious metals (cobalt, nickel and aluminium) [112], thereby reducing the cost of the system [113]. Nieves Urena et al. reported on amphiphilic semi-interpenetrating polymer networks for AEMFC applications with three dissimilar ionic groups, namely, tetramethyl ammonium, 1-methylimidazolium, and 1,2-dimethylimidazolium and cross-linked with $\mathrm{N}, \mathrm{N}, \mathrm{N}^{\prime}, \mathrm{N}^{\prime}$-tetramethylethylenediamine (TMEDA) [114]. The resulting membrane exhibits the following characteristic: (i) at low temperatures (lower than $100{ }^{\circ} \mathrm{C}$ ) has high thermal stability, (ii) lower water uptake at ambient temperature, (iii) acceptable hydroxyl ion conductivity, (iv) outstanding chemical stability, (v) excellent dimensional stability because of the inferior water uptake. Furthermore, the membrane showed excellent alkaline stability. Recently, Yang Bai et al. prepared quaternized polysulfone-based AEMS cross-linked with rGO (CQPSU-X-rGO) functionalized with different chain length small molecules [115]. Especially, the functionalized CQPSU-X-rGO showed improved ionic conductivity and chemical stability. The maximum ionic conductivity of $0.140 \mathrm{~S} \mathrm{~cm}^{-1}$ at $80^{\circ} \mathrm{C}$ was achieved for rGO cross-linked AEMS. Tiantian Li et al. synthesized PSU based anion exchange membrane via Friedel-Crafts alkylation method contains pendant imidazolium functionalized side chain to avoid conventional carcinogenic chloromethylation. It does not require any special functional groups on the polymeric materials, which is the main advantage compared with other mentioned chloromethylation-free routes in the literature [116]. Furthermore, the membranes synthesized in this methodology displayed excellent ionic conductivity and swelling ratio along with good mechanical, thermal, and alkaline stabilities. Very recently, Lingling Ma et al. synthesized a series of AEMs modified with bulky rigid -cyclodextrin (CD) and long flexible multiple quaternary ammonium (MQ) membrane for AMFC applications [117]. The resulting AEM with a relatively low IEC of 1.50 meq. $\mathrm{g}^{-1}$ exhibits a good ionic conductivity of $112.4 \mathrm{mS} \mathrm{cm}^{-1}$ at $80^{\circ} \mathrm{C}$, whereas its counterpart without $\mathrm{CD}$ modification shows $83.0 \mathrm{mS} \mathrm{cm}^{-1}$ despite a similar ion exchange capacity $\left(1.60\right.$ meq. $\left.\mathrm{g}^{-1}\right)$. This is because large $C D$ units can impart a high free volume 
to the membrane, dropping the ion transfer resistance, while the hydrophilicity of the external surface of the CD can promote the formation of ion transport channels across the long flexible MQ cross-links. The fabricated $\mathrm{H}_{2} / \mathrm{O}_{2} \mathrm{FC}$ provides a maximum PD of $288 \mathrm{~mW} \mathrm{~cm}^{-1}$ at $60^{\circ} \mathrm{C}$. Mona Iravaninia et al. prepared AEM from polysulfone membrane by a conventional three-step method, chloromethylation, amination, alkalization with functionalized trimethylamine and $\mathrm{N}, \mathrm{N}, \mathrm{N}^{\prime}, \mathrm{N}^{\prime}$-tetramethyl-1.6-hexanediamine [118]. The prepared membrane exhibited ionic conductivity of $2-42 \mathrm{mS} \mathrm{cm}^{-1}$ at $25-80{ }^{\circ} \mathrm{C}$ in different RH. The IECs, anion transport numbers, and hydration numbers were within the range of 1.6-2.1 meq. $\mathrm{g}^{-1}, 0.95-0.98$ and 9-16, respectively. Furthermore, the single $\mathrm{H}_{2} / \mathrm{O}_{2}$ fuel cell showed a OCV of $1.05 \mathrm{~V}$ and a maximum PD of $110 \mathrm{~mW} \mathrm{~cm}^{-2}$ at $60{ }^{\circ} \mathrm{C}$. Yang Bai et al. proposed a facile strategy to construct rGO stable cross-linked PSU-based AEMs with enhanced properties [119]. The cross-linked AEMS can constrict the internal packing structure and improve alkaline stability, ion conductivity, and oxidative stability. The rGO crosslinked AEM showed higher ionic conductivity of $117.7 \mathrm{mS} \mathrm{cm}^{-1}$ at $80^{\circ} \mathrm{C}$. Wan Liu et al. derived AEM from QPSU and exfoliated LDH for fuel cell applications [120]. The composite membrane comprising 5\% LDH sheets showed good performance, displaying an ionic conductivity of $0.0235 \mathrm{~S} \mathrm{~cm}^{-1}$ at $60{ }^{\circ} \mathrm{C}$. Yuliang Jiang et al. reported a series of PSU-based AEMs with cross-linker, 4, 4'-trimethyenedipiperidine (TMDP) [121]. The cross-linked aminated polysulfone (CAPSF) displayed supreme alkaline stability compared with noncrosslinked aminated polysulfone (APSF) in $1 \mathrm{M} \mathrm{KOH}$ for 15 days at $333 \mathrm{~K}$. Furthermore, the CAPSF exhibits better dimensional stability as compared with the non-cross-linked APSF membrane owing to the compact interconnected architecture formation. From the above results, the authors concluded that the prepared crosslinked AEM is a potential candidate for AMFCs. Maria Teresa Perez-Prior et al. prepared crosslinked polysulfone AEMs using 1,4-diazabicyclo [2,2,2] octane (DABCO) as cross-liner [122]. The obtained results revealed that the cross-linked membranes displayed exceptional thermal stability, improved water uptake and dimensional stability as compared with non-cross-linked AEM. Prerana Sharma et al. described a novel strategy to synthesize alkaline membrane of chloromethylated polysulfone using cross-linker, 4,4' (3,3'-bis(chloromethyl)-[1,1'-bipheny]4,4-diyl)bis(oxy))dianiline) (BCBD) [123]. The detailed reaction pathway of cross-linked quaternary polysulfone (CR-QPS) membrane is shown in Figure 8. The cross-linked membrane performed well in AMFCs and exhibited maximum OCV of $0.813 \mathrm{~V}$ and PD of $103.6 \mathrm{~mW} \mathrm{~cm}^{-2}$ at $260 \mathrm{~mA} \mathrm{~cm}^{-2}$

P. F. Msomi et al. reported a sequence of AEM comprised of poly(2,6-dimethyl-1,4phenylene) (PPO) and PSF blended with titania (QPPO/PSF/ $\mathrm{TiO}_{2}$ ) [124]. The swelling ratio, ionic conductivity, water uptake, and IEC of the composite were enhanced by multiplying the titania filler content. Furthermore, the QPSU/PSF $/ 2 \% \mathrm{TiO}_{2}$ displayed a supreme PD of $118 \mathrm{~mW} \mathrm{~cm}^{-2}$ at $60{ }^{\circ} \mathrm{C}$ with excellent membrane stability over $60 \mathrm{~h}$. K. Rambabu et al. described imidazolium functionalized PSF membranes modified with zirconia (Im$\mathrm{PSF} / \mathrm{ZrO}_{2}$ ) by solution casting method for AMFC applications [125]. The enhanced water absorption, IEC (2.84 meq. $\left.\mathrm{g}^{-1}\right)$, hydroxyl ion conductivity $\left(80.2 \mathrm{mS} \mathrm{cm}^{-1}\right.$ at $\left.50{ }^{\circ} \mathrm{C}\right)$, and thermal resistance achieved for Im-PSF $/ \mathrm{ZrO}_{2}$ composite membrane as compared with pristine Im-PSF, which confirms the strong adhesion and property enhancement caused by zirconia. Furthermore, the composite membrane with Im-PSF $/ 10 \% \mathrm{ZrO}_{2}$ showed a maximum PD of $270 \mathrm{~mW} \mathrm{~cm} \mathrm{~cm}^{-2}$ with $\mathrm{OCV}$ of $1.04 \mathrm{C}$ in $\mathrm{H}_{2} / \mathrm{O}_{2}$ fueled AMFCs.

In summary, prominent developments have been made for the use of quaternized polysulfone with AEM in alkaline membrane fuel cells with respect to thermal, electrochemical, mechanical stability, and hydroxyl ion conductivity. Furthermore, virtuous advancement has been achieved regarding the impregnation of various inorganic filler or ionic liquids or polymer blend into various polymeric assemblies where the resultant AEMs accomplished rational performance when tested in AMFCs. 


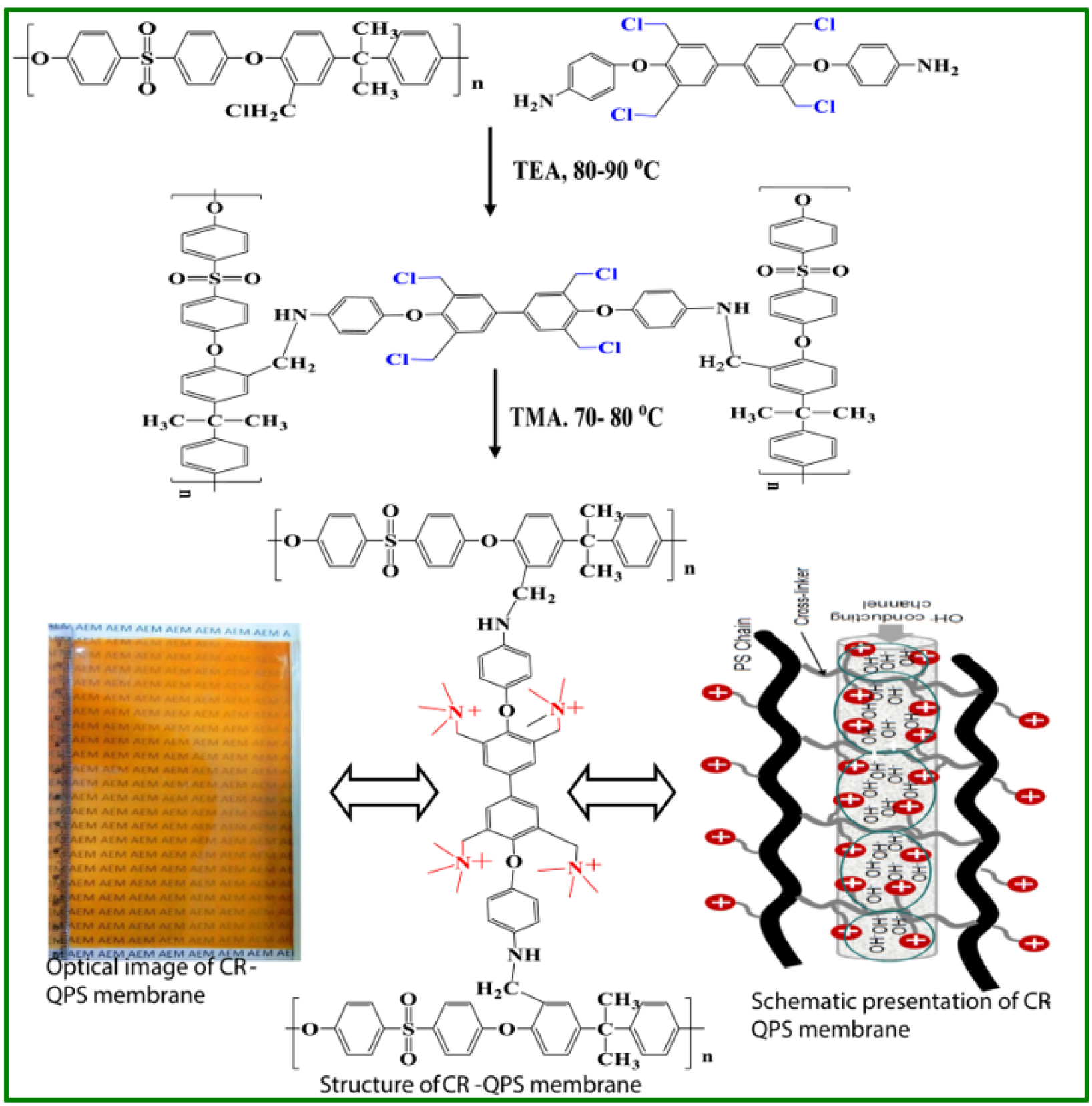

Figure 8. Schematic illustration for synthesis of CR-QPS AEM. Reproduced with the permission from [123]. Copyright 2020 Elsevier.

\section{Conclusions and Future Perspectives}

The emerging fuel cell market is a strong driving force for the scientific community to achieve new, affordable, and high-performance membrane materials. The present review deals with the recent advancements of polysulfone-based proton exchange membrane/anion exchange membrane for PEMFCs, DMFCs, and AMFCs application. Polysulfone-derived $\mathrm{PEM} / \mathrm{AEM}$ and its composites are exploited a crucial role in the fuel cell applications as evidenced by the ample literature that is available. For PEMFCs/DMFCs, sulfonated polysulfone and its composites with inorganic fillers, layered double hydroxides, metal-organic frameworks have been investigated in this present review. Specifically, water uptake, ionic $\left(\mathrm{H}^{+}\right)$conductivity, methanol permeability, alkaline stability, and the performance of fuel cell substantially enhanced as compared with pristine sulfonated polysulfone. Furthermore, many polymer electrolyte membranes reported in this review showed a better fuel cell performance and reduced methanol crossover compared with commercially available Nafion 
membranes in both PEMFCs and DMFCs operation. However, still Nafion membranes were used in the industrial sector and transport vehicles. Therefore, the commercialization of the PEMs is the utmost priority to every researcher in the membrane study to overcome Nafion membrane for PEMFCs/DMFCs applications.

As deliberated, the use of AEMs in electrochemical systems could potentially eliminate the common issues such as fuel crossover, confronted in PEMFCs. Additionally, the use of AEMs has several advantages, such as being used in alkaline environments, which enables the use of non-precious metal catalysts. Nevertheless, numerous problems need to be fixed such as poor ionic conductivity (which is accountable for poor voltage efficiency and ohmic losses), insufficient membrane stability in alkaline and oxidative atmospheres, and a lack of suitable alkaline ionomers, especially for AMFCs. Several conventional methods have been extensively studied to improve the ionic conductivity of AEMs. Recently, interpenetrating polymer network (IPN) and pore-enriched composite AEMs have efficiently imitated the Nafion-like morphology, where the hydrophobic polyolefin and the hydrophilic quaternized polymer moiety are well disconnected. As a result, a fabulous enhancement in the ionic conductivity could be attained. Inclusive data regarding the oxidative stability of AEMs can inspire further work towards the modification of existing materials or the development of new materials for AEMs. The development of AEMs based on PEEK, polybenzimidazole, and functional group chemistries based on imidazolium and guanidinium are still in the early stages. Therefore, the chemical stability of these AEMs can be studied in detail and their performance in electrochemical systems can be explored extensively.

Furthermore, the aminated/quaternized polysulfone blended with other polymers or the incorporation of inorganic fillers, such as silica, titania, zirconia, zeolites, metal-organic frameworks, etc., hinder the ionic conductivity and may reduce the chemical stability of the AEM. Despite their low alkaline stability, AEMs is still an important research field with a great outlook due to their outstanding advantages over PEMFCs. Therefore, there is an urgent need to progress novel AEMs that attain a high ionic conductivity and selectivity and exhibit outstanding chemical stability in alkaline conditions and high temperatures.

Author Contributions: Investigation and writing-original draft, R.V.; Investigation and visualization, R.A.; Conceptualization and validation, H.-J.K.; Project administration and supervision, M.Y. All authors have read and agreed to the published version of the manuscript.

Funding: This research was funded by BK21 Plus Creative Human Resource Education and Research Programs for ICT Convergence in the 4th Industrial Revolution, Pusan National University, Busan, South Korea.

Institutional Review Board Statement: Not applicable.

Informed Consent Statement: Not applicable.

Data Availability Statement: The data presented in this study are available on request from the corresponding author.

Acknowledgments: The authors gratefully acknowledge financial support from BK21 Plus Creative Human Resource Education and Research Programs for ICT Convergence in the 4th Industrial Revolution, Pusan National University, Busan, South Korea.

Conflicts of Interest: The authors declare no conflict of interest.

\section{References}

1. Kordesch, K.V.; Simader, G.R. Environmental impact of fuel cell technology. Chem. Rev. 1995, 95, 191-207. [CrossRef]

2. Yan, Q.; Toghiani, H.; Causey, H. Steady state and dynamic performance of proton exchange membrane fuel cells (PEMFCs) under various operating conditions and load changes. J. Power Sources 2006, 161, 492-502. [CrossRef]

3. Barbir, F.; Gómez, T. Efficiency and economics of proton exchange membrane (PEM) fuel cells. Int. J. Hydrogen Energy 1997, 22, 1027-1037. [CrossRef]

4. Kacprzak, A. Hydroxide electrolyte direct carbon fuel cells-technology review. Int. J. Energy Res. 2018, 43, 65-85. [CrossRef] 
5. Zakaria, Z.; Kamarudin, S.K.; Timmiati, S. Membranes for direct ethanol fuel cells: An overview. Appl. Energy 2016, 163, 334-342. [CrossRef]

6. Steele, B.; Heinzel, A. Materials for fuel-cell technologies. Nature 2001, 414, 345-352. [CrossRef] [PubMed]

7. Carrette, L.; Friedrich, K.A.; Stimming, U. Fuel cells-fundamentals and applications. Fuel Cells 2001, 1, 5-39. [CrossRef]

8. Araya, S.S.; Andreasen, S.J.; Nielsen, H.V.; Kaer, S.K. Investigating the effects of methanol-water vapor mixture on a PBI-based high temperature PEM fuel cell. Int. J. Hydrogen Energy 2012, 37, 18231-18242. [CrossRef]

9. Haile, S.M. Fuel cell materials and components. Acta Mater. 2003, 51, 5981-6000. [CrossRef]

10. Kordesch, K.; Simader, G. Fuel Cells and Their Applications; VCH: Weinheim, Germany, 1996.

11. Pineri, M.; Eisenberg, A. Structure and Properties of Ionomers; Springer: Dordrecht, The Netherlands, 1987.

12. Samms, S.R.; Wasmus, S.; Savinell, R.F. Thermal stability of nafion ${ }^{\circledR}$ in simulated fuel cell environments. J. Electrochem. Soc. 1996, 143, 1498. [CrossRef]

13. Uosaki, K.; Okazaki, K.; Kita, H. Conductivity of Nation membranes at low temperatures. J. Electroanal. Chem. Interfacial. Electrochem. 1990, 287, 163-169. [CrossRef]

14. Cappadonia, M.; Erning, J.W.; Niaki, S.M.S.; Stimming, U. Conductance of Nafion 117 membranes as a function of temperature and water content. Solid State Ion. 1995, 77, 65-69. [CrossRef]

15. Adjemian, K.T.; Srinivasan, S.; Benziger, J.; Bocarsly, A.B. Investigation of PEMFC operation above $100{ }^{\circ} \mathrm{C}$ employing perfluorosulfonic acid silicon oxide composite membranes. J. Power Sources 2002, 109, 356-364. [CrossRef]

16. Kim, Y.M.; Choi, S.H.; Lee, H.C.; Hong, M.Z.; Kim, K.; Lee, H.-I. Organic-inorganic composite membranes as addition of SiO 2 for high temperature-operation in polymer electrolyte membrane fuel cells (PEMFCs). Electrochim. Acta 2004, 49, 4787-4796. [CrossRef]

17. Antonucci, P.L.; Arico, A.S.; Creti, P.; Ramunni, E.; Antonucci, V. Investigation of a direct methanol fuel cell based on a composite Nafion ${ }^{\circledR}$-silica electrolyte for high temperature operation. Solid State Ion. 1999, 125, 431-437. [CrossRef]

18. Seyed, H.-S.; Gholamreza, B.; Mohammad, S.L. Performance of the sulfonated poly ether ether ketone proton exchange membrane modified with sulfonated polystyrene and phosphotungstic acid for microbial fuel cell applications. J. Appl. Polym. Sci. 2021, 138, 50430.

19. Martina, P.; Gayathri, R.; Raja Pugalenthi, M.; Cao, G.; Liu, C.; Ramesh Prabhu, M. Nanosulfonated silica incorporated SPEEK/SPVdF-HFP polymer blend membrane for PEM fuel cell application. Ionics 2020, 26, 3447-3458. [CrossRef]

20. Mader, J.A.; Benicewicz, B.C. Sulfonated Polybenzimidazoles for High Temperature PEM Fuel Cells. Macromolecules 2010, 43, 6706-6715. [CrossRef]

21. Singha, S.; Jana, T.; Modestra, J.A.; Kumar, A.N.; Mohan, S.V. Highly efficient sulfonated polybenzimidazole as a proton exchange membrane for microbial fuel cells. J. Power Sources 2016, 317, 143-152. [CrossRef]

22. Lufrano, F.; Squadrito, G.; Patti, A.; Passalacqua, E. Sulfonated polysulfone as promising membranes for polymer electrolyte fuel cells. J. Appl. Polym. Sci. 2000, 77, 1250-1256. [CrossRef]

23. Zhao, T.S.; Kreuer, K.D.; Nguyen, T.V. Advances in Fuel Cells; Elsevier Ltd.: Amsterdam, The Netherlands, 2007.

24. Srinivasan, S. Fuel Cells: From Fundamentals to Applications; Springer: Berlin, Germany, 2006.

25. Kamarudin, S.K.; Daud, W.R.W.; Ho, S.L.; Hasran, U.A. Overview on the challenges and developments of micro-direct methanol fuel cells (DMFC). J. Power Sources 2007, 163, 743-754. [CrossRef]

26. Zaidi, S.M.; Matsuura, T. Polymer Membranes for Fuel Cells; Springer Science: Berlin, Germany, 2009.

27. Li, N.; Fane, A.; Ho, W.S.; Matsuura, T. Advanced Membrane Technology and Applications; John Wiley \& Sons, Inc.: Hoboken, NJ, USA, 2008.

28. Zhao, T.S.; Xu, C.; Chen, R.; Yang, W.W. Mass transport phenomena in direct methanol fuel cells. Prog. Energy Combust. Sci. 2009, 35, 275-292. [CrossRef]

29. Dai, J.; He, G.; Ruan, X.; Zheng, W.; Pan, Y.; Yan, X. Constructing a rigid crosslinked structure for enhanced conductivity of imidazolium functionalized polysulfone hydroxide exchange membrane. Int. J. Hydrogen Energy 2016, 41, 10923-10934. [CrossRef]

30. Mohanty, A.D.; Tignor, S.E.; Krause, J.A.; Choe, Y.K.; Bae, C. Systematic alkaline study of polymer backbones for anion exchange membrane applications. Macromolecules 2016, 49, 3361-3372. [CrossRef]

31. Pan, Y.; Wang, T.Y.; Yan, X.M.; Xu, X.W.; Zhang, Q.D.; Zhao, B.L.; El Hamouti, I.; Hao, C.; He, G.H. Novel benzimidazolium functionalized polysulfone-based anion exchange membranes with improved alkaline stability. Chin. J. Polym. Sci. 2018, 36, 129-138. [CrossRef]

32. Vinodh, R.; Ilakkiya, A.; Elamathi, S.; Sangeetha, D. A novel anion exchange membrane from polystyrene (ethylene butylene) polystyrene: Synthesis and characterization. Mater. Sci. Eng. B 2010, 167, 43-50. [CrossRef]

33. Liu, L.; Chu, X.; Liao, J.; Huang, Y.; Li, Y.; Ge, Z.; Hickner, M.A.; Li, N. Tuning the properties of Poly(2,6-dimethyl-1,4-phenylene oxide) anion exchange membranes and their performance in $\mathrm{H}_{2} / \mathrm{O}_{2}$ fuel cells. Energy Environ. Sci. 2018, 11, 435-446. [CrossRef]

34. Zhang, W.; Liu, Y.; Horan, J.L.; Jin, Y.; Ren, X.; Ertem, S.P.; Seifert, S.; Liberatore, M.W.; Herring, A.M.; Coughlin, E.B. Crosslinked anion exchange membranes with connected cations. J. Polym. Sci. Part A Polym. Chem. 2017, 56, 618-625. [CrossRef]

35. Shukla, G.; Shahi, V.K. Poly(arylene ether ketone) copolymer grafted with amine groups containing long alkyl chain by chloroacetylation for improved alkaline stability and conductivity of anion exchange membrane. ACS Appl. Energy Mater. 2018, 1, 1175-1182. [CrossRef] 
36. Zuo, D.; Gong, Y.; Yan, Q.; Zhang, H. Preparation and characterization of hydroxyl ion-conducting interpenetrating polymer network based on PVA and PEI. J. Polym. Res. 2016, 23, 126-132. [CrossRef]

37. Guo, D.; Lai, A.N.; Lin, C.X.; Zhang, Q.G.; Zhu, A.M.; Liu, Q.L. Imidazolium-functionalized poly(arylene ether sulfone) anionexchange membranes densely grafted with flexible side chains for fuel cells. ACS Appl. Mater. Interfaces 2016, 8, 25279-25288. [CrossRef] [PubMed]

38. Pérez-Prior, M.T.; Várez, A.; Levenfeld, B. Synthesis and characterization of benzimidazolium-functionalized polysulfones as anion-exchange membranes. J. Polym. Sci. Part A Polym. Chem. 2015, 53, 2363-2373. [CrossRef]

39. Yan, X.; Gu, S.; He, G.; Wu, X.; Zheng, W.; Ruan, X. Quaternary phosphonium-functionalized poly(ether ether ketone) as highly conductive and alkali-stable hydroxide exchange membrane for fuel cells. J. Membr. Sci. 2014, 466, 220-228. [CrossRef]

40. Jangu, C.; Long, T.E. Phosphonium cation-containing polymers: From ionic liquids to polyelectrolytes. Polymer 2014, 55, 3298-3304. [CrossRef]

41. Liu, L.; Li, Q.; Dai, J.; Wang, H.; Jin, B.; Bai, R. A facile strategy for the synthesis of guanidinium-funcionalized polymer as alkaline anion exchange membrane with improved alkaline stability. J. Membr. Sci. 2014, 453, 52-60. [CrossRef]

42. Kim, D.S.; Fujimoto, C.H.; Hibbs, M.R.; Labouriau, A.; Choe, Y.-K.; Kim, Y.S. Resonance stabilized perfluorinated ionomers for alkaline membrane fuel cells. Macromolecules 2013, 46, 7826-7833. [CrossRef]

43. Cha, M.S.; Lee, J.Y.; Kim, T.-H.; Jeong, H.Y.; Shin, H.Y.; Oh, S.-G.; Hong, Y.T. Preparation and characterization of crosslinked anion exchange membrane (AEM) materials with poly(phenylene ether)-based short hydrophilic block for use in electrochemical applications. J. Membr. Sci. 2017, 530, 73-83. [CrossRef]

44. Huang, X.L.; Lin, C.X.; Hu, E.N.; Soyekwo, F.; Zhang, Q.G.; Zhu, A.M.; Liu, Q.L. Imidazolium-functionalized anion exchange membranes using poly(ether sulfone)s as macrocrosslinkers for fuel cells. RCS Adv. 2017, 7, 27342-27353. [CrossRef]

45. Gong, X.; Yan, X.; Li, T.; Wu, X.; Chen, W.; Huang, S.; Wu, Y.; Zhen, D.; He, G. Design of pendent imidazolium side with flexible ether-containing spacer for alkaline anion exchange membrane. J. Membr. Sci. 2017, 523, 216-224. [CrossRef]

46. Hugar, K.M.; Kostalik, H.A., IV; Coates, G.W. Imidazolium cations with exceptional alkaline stability: A systematic study of structure-stability relationships. J. Am. Chem. Soc. 2015, 137, 8730-8737. [CrossRef] [PubMed]

47. Grew, K.N.; Chiu, W.K.S. A dusty fluid model for predicting hydroxyl anion conductivity in alkaline anion exchange membranes. J. Electrochem. Soc. 2010, 157, B327. [CrossRef]

48. Hren, M.; Božič, M.; Fakin, D.; Kleinschek, K.S.; Gorgieva, S. Alkaline membrane fuel cells: Anion exchange membranes and fuels. Sustain. Energy Fuels 2021, 5, 604-637. [CrossRef]

49. Sun, C.; Zlotorowicz, A.; Nawn, G.; Negro, E.; Bertasi, F.; Pagot, G.; Vezzù, K.; Pace, G.; Guarnieri, M.; Noto, V.D. [Nafion/(WO 3$\left.)_{x}\right]$ hybrid membranes for vanadium redox flow batteries. Solid State Ion. 2018, 319, 110-116. [CrossRef]

50. Vinodh, R.; Sangeetha, D. Quaternized Poly(Styrene Ethylene Butylene Poly Styrene)/Multiwalled Carbon Nanotube Composites for Alkaline Fuel Cell Applications. J. Nanosci. Nanotechnol. 2013, 13, 5522-5533. [CrossRef]

51. Vinodh, R.; Sangeetha, D. Efficient utilization of anion exchange composites using silica filler for low temperature alkaline membrane fuel cells. Int. J. Plast. Technol. 2013, 17, 35-50. [CrossRef]

52. Di, S.; Yan, L.; Han, S.; Yue, B.; Feng, Q.; Xie, L.; Chen, J.; Zhang, D.; Sun, C. Enhancing the high-temperature proton conductivity of phosphoric acid doped poly(2,5-benzimidazole) by preblending boron phosphate nanoparticles to the raw materials. J. Power Sources 2012, 211, 161-168. [CrossRef]

53. Vinodh, R.; Sangeetha, D. Comparative study of composite membranes from nano-metal-oxide-incorporated polymer electrolytes for direct methanol alkaline membrane fuel cells. J. Appl. Polym. Sci. 2013, 128, 1930-1938. [CrossRef]

54. Santoyo, A.B.; Carraso, J.L.G.; Gomez, E.G.; Martin, F.M.; Montesinos, A.M.H. Application of reverse osmosis to reduce pollutants present in industrial waste water. Desalination 2003, 155, 101-108. [CrossRef]

55. Nechifor, G.; Voicu, S.I.; Nechifor, A.C.; Garea, S. Nanostructured hybrid membrane polysulfone-carbon nanotubes for hemodialysis. Desalination 2009, 241, 342-348. [CrossRef]

56. Arico, A.S.; Srinivasan, S.; Antonucci, V. DMFCs from fundamental aspects to technology development. Fuel Cells 2001, 1, 133-161. [CrossRef]

57. Dillon, R.; Srinivasan, S.; Arico, A.S.; Antonucci, V. International activities in DMFC R\&D: Status of technologies and potential applications. J. Power Sources 2004, 127, 112-126.

58. Kariduraganavar, M.Y.; Munavalli, B.B.; Torvi, A.I. Proton conducting polymer electrolytes for fuel cells via electrospinning technique. In Organic-Inorganic Composite Polymer Electrolyte Membranes: Preparation, Properties and Fuel Cell Applications; Inamuddin, Mohammad, A., Asiri, A.M., Eds.; Springer International Publishing: New York, NY, USA, 2017; pp. 421-458.

59. Kraytsberg, A.; Eli, Y.E. A review of advanced, materials for proton exchange membrane fuel cells. Energy Fuels 2014, 28, 7303-7330. [CrossRef]

60. Muller, F.; Ferreira, C.A.; Azambuja, D.S.; Aleman, C.; Armelin, E. Measuring the proton conductivity of ion-exchange membranes using electrochemical impedance spectroscopy and through-plane cell. J. Phys. Chem. B 2014, 118, 1102-1112. [CrossRef] [PubMed]

61. Peighambardoust, S.J.; Rowshanzamir, S.; Amjadi, M. Review of the proton exchange membranes for fuel cell applications. Int. J. Hydrogen Energy 2010, 35, 9349-9384. [CrossRef]

62. Munavalli, B.; Torvi, A.; Kariduraganavar, M. A facile route for the preparation of proton exchange membranes using sulfonated side chain graphite oxides and crosslinked sodium alginate for fuel cell. Polymer 2018, 142, 293-309. [CrossRef] 
63. Li, Z.; He, G.; Zhao, Y.; Cao, Y.; Wu, H.; Li, Y.; Jiang, Z. Enhanced proton conductivity of proton exchange membranes by incorporating sulfonated metal-organic frameworks. J. Power Sources 2014, 262, 372-379. [CrossRef]

64. Liang, X.; Zhang, F.; Feng, W.; Zou, X.; Zhao, C.; Na, H.; Liu, C.; Sun, F.; Zhu, G. From metal-organic framework (MOF) to MOF-polymer composite membrane: Enhancement of low-humidity proton conductivity. Chem. Sci. 2013, 4, 983-992. [CrossRef]

65. Ren, Y.; Chia, G.H.; Gao, Z. Metal-organic frameworks in fuel cell technologies. Nano Today 2013, 8, 577-597. [CrossRef]

66. Horike, S.; Umeyama, D.; Kitagawa, S. Ion conductivity and transport by porous coordination polymers and metal-organic frameworks. Acc. Chem. Res. 2013, 46, 2376-2384. [CrossRef] [PubMed]

67. Ahmadian-Alam, L.; Mahdavi, H. A novel polysulfone-based ternary nanocomposite membrane consisting of metal-organic framework and silica nanoparticles: As proton exchange membrane for polymer electrolyte fuel cells. Renew. Energy 2018, 126, 630-639. [CrossRef]

68. Nor, N.A.M.; Nakao, H.; Jaafar, J.; Kim, J.-D. Crosslinked carbon nanodots with highly sulfonated polyphenylsulfone as proton exchange membrane for fuel cell applications. Int. J. Hydrogen Energy 2020, 45, 9979-9988.

69. Munavalli, B.B.; Kariduraganavar, M.Y. Development of novel sulfonic acid functionalized zeolites incorporated composite proton exchange membranes for fuel cell application. Electrochim. Acta 2017, 296, 294-307. [CrossRef]

70. Li, J.; Wu, H.; Cao, L.; He, X.; Shi, B.; Li, Y.; Xu, M.; Jiang, Z. Enhanced proton conductivity of sulfonated polysulfone membranes under low humidity via the incorporation of multifunctional graphene oxide. ACS Appl. Nano Mater. 2019, 2, $4734-4743$. [CrossRef]

71. Simari, C.; Lufrano, E.; Brunetti, A.; Barbieri, G.; Nicotera, I. Highly-performing and low-cost nanostructured membranes based on Polysulfone and layered doubled hydroxide for high-temperature proton exchange membrane fuel cells. J. Power Sources 2020, 471, 228440. [CrossRef]

72. Pan, T.; Yue, B.; Yan, L.; Zeng, G.; Hu, Y.; He, S.; Lu, W.; Zhao, H.; Zhang, J. N,N-bis(sulfopropyl)aminyl-4-phenyl polysulfone and $\mathrm{O}, \mathrm{O}^{\prime}$-bis(sulfopropyl)resorcinol-5-yl-4-phenyl polysulfone composite membrane for proton exchange membrane fuel cells. Int. J. Hydrogen Energy 2020, 45, 23490-23503. [CrossRef]

73. Mahimai, B.M.; Kulasekaran, P.; Deivanayagam, P. Novel polysulfone/sulfonated polyaniline/niobium pentoxide polymer blend nanocomposite membranes for fuel cell applications. J. Appl. Polym. Sci. 2021, 138, 51207. [CrossRef]

74. Han, S.; Yue, B.; Yan, L. Research progress in the development of high-temperature proton exchange membranes based on phosphonic acid group. Acta Phys. Chim. Sin. 2014, 30, 8-21.

75. Stone, C.; Daynard, T.; Hu, L.; Mah, C.; Steck, A. Phosphonic acid functionalized proton exchange membranes for PEM fuel cells. J. New Mat. Electr. Sys. 2000, 3, 43-50.

76. Bock, T.; Möhwald, H.; Mülhaupt, R. Arylphosphonic acid-functionalized polyelectrolytes as fuel cell membrane material. Macromol. Chem. Phys. 2007, 208, 1324-1340. [CrossRef]

77. Herath, M.B.; Creager, S.E.; Kitaygorodskiy, A.; DesMarteau, D.D. Perfluoroalkyl phosphonic and phosphinic acids as proton conductors for anhydrous proton-exchange membranes. Chem. Phys. Chem. 2010, 11, 2871-2878. [CrossRef]

78. Paddison, S.J.; Kreuer, K.-D.; Maier, J. About the choice of the protogenic group in polymer electrolyte membranes: Ab initio modelling of sulfonic acid, phosphonic acid, and imidazole functionalized alkanes. Phys. Chem. Chem. Phys. 2006, 8, 4530-4542. [CrossRef] [PubMed]

79. Yu, L.; Yue, B.; Yan, L.; Zhao, H.; Zhang, J. Proton conducting composite membranes based on sulfonated polysulfone and polysulfone-g-(phosphonated polystyrene) via controlled atom-transfer radical polymerization for fuel cell applications. Solid State Ion. 2019, 338, 103-112. [CrossRef]

80. Yang, J.; Li, Q.; Cleemann, L.N.; Jensen, J.O.; Pan, C.; Bjerrum, N.J.; He, R. Crosslinked hexafluoropropylidene polybenzimidazole membranes with chloromethyl polysulfone for fuel cell applications. Adv. Energy Mater. 2013, 3, 622-630. [CrossRef]

81. Bai, H.; Wang, H.; Zhang, J.; Wu, C.; Zhang, J.; Xiang, Y.; Lu, S. Simultaneously enhancing ionic conduction and mechanical strength of poly(ether sulfones)-poly(vinyl pyrrolidone) membrane by introducing graphitic carbon nitride nanosheets for high temperature proton exchange membrane fuel cell application. J. Membr. Sci. 2018, 558, 26-33. [CrossRef]

82. Tang, H.; Geng, K.; Hu, Y.; Li, N. Synthesis and properties of phosphonated polysulfones for durable high-temperature proton exchange membranes fuel cell. J. Membr. Sci. 2020, 605, 118107. [CrossRef]

83. Zhang, J.; Zhang, J.; Bai, H.; Tan, Q.; Wang, H.; He, B.; Xiang, Y.; Lu, S. A new high temperature polymer electrolyte membrane based on trifunctional group grafted polysulfone for fuel cell application. J. Membr. Sci. 2019, 572, 496-503. [CrossRef]

84. Bai, H.; Wang, H.; Zhang, J.; Zhang, J.; Lu, S.; Xiang, Y. High temperature polymer electrolyte membrane achieved by grafting poly (1-vinylimidazole) on polysulfone for fuel cells application. J. Membr. Sci. 2019, 592, 117395. [CrossRef]

85. Devi, A.U.; Muthumeenal, A.; Sabarathinam, R.; Nagendran, A. Fabrication and electrochemical properties of SPVdF-coHFP/SPES blend proton exchange membranes for direct methanol fuel cells. Renew. Energy 2017, 102, 258-265. [CrossRef]

86. Azimi, M.; Peighambardoust, S. Methanol crossover and selectivity of nafion/heteropolyacid/. montmorillonite nanocomposite proton exchange membranes for DMFC Applications. Iran. J. Chem. Eng. 2017, 14, 65-81.

87. Yilmaz, E.; Can, E. Cross-linked poly (aryl ether sulfone) membranes for direct methanol fuel cell applications. J. Polym. Sci. B Polym. Phys. 2018, 56, 558-575. [CrossRef]

88. Bhavani, P.; Sangeetha, D. Blend membranes for direct methanol and proton exchange membrane fuel cells. Chin. J. Polym. Sci. 2012, 30, 548-560. [CrossRef] 
89. Muthumeenal, A.; Neelakandan, S.; Kanagaraj, P.; Nagendran, A. Synthesis and properties of novel proton exchange membranes based on sulfonated polyethersulfone and N-phthaloyl chitosan blends for DMFC applications. Renew. Energy 2016, 86, 922-929. [CrossRef]

90. Clarizia, G.; Tasselli, F.; Simari, C.; Nicotera, I.; Bernardo, P. Solution casting blending: An effective way for tailoring gas transport and mechanical properties of poly(vinyl butyral) and Pebax2533. J. Phys. Chem. C 2019, 123, 11264-11272. [CrossRef]

91. Simari, C.; Lufrano, E.; Coppola, L.; Nicotera, I. Composite gel polymer electrolytes based on organo-modified nanoclays: Investigation on lithium-ion transport and mechanical properties. Membranes 2018, 8, 69. [CrossRef]

92. Nohara, T.; Koseki, K.; Tabata, K.; Shimada, R.; Suzuki, Y.; Umemoto, K.; Takeda, M.; Sato, R.; Rodbuntum, S.; Arita, T.; et al. Core size-dependent proton conductivity of silica filler-functionalized polymer electrolyte membrane. ACS Sustain. Chem. Eng. 2020, 8 , 14674-14678. [CrossRef]

93. Devrim, Y.; Erkan, S.; Bac, N.; Eroğlu, I. Preparation and characterization of sulfonated polysulfone/titanium dioxide composite membranes for proton exchange membrane fuel cells. Int. J. Hydrogen Energy 2009, 34, 3467-3475. [CrossRef]

94. Borduin, R.; Li, W. Fabrication of foamed polyethersulfone-zeolite mixed matrix membranes for polymer electrolyte membrane fuel cell humidification. J. Manuf. Sci. Eng. 2017, 139, 021004. [CrossRef]

95. Sakamoto, M.; Nohara, S.; Miyatake, K.; Uchida, M.; Watanabe, M.; Uchida, H. Effects of incorporation of SiO2 nanoparticles into sulfonated polyimide electrolyte membranes on fuel cell. performance under low humidity conditions. Electrochim. Acta 2014, 137, 213-218. [CrossRef]

96. de Bonis, C.; Simari, C.; Kosma, V.; Mecheri, B.; D’Epifanio, A.; Allodi, V.; Mariotto, G.; Brutti, S.; Suarez, S.; Pilar, K.; et al. Enhancement of proton mobility and mitigation of methanol crossover in sPEEK fuel cells by an organically modified titania nanofiller. J. Solid State Electrochem. 2016, 20, 1585-1598. [CrossRef]

97. Simari, C.; Stallworth, P.; Peng, J.; Coppola, L.; Greenbaum, S.; Nicotera, I. Graphene oxide and sulfonated-derivative: Proton transport properties and electrochemical behavior of Nafion based nanocomposites. Electrochim. Acta 2019, 297, $240-249$. [CrossRef]

98. Simari, C.; Potsi, G.; Policicchio, A.; Perrotta, I.; Nicotera, I. Clay carbon nanotubes hybrid materials for nanocomposite membranes: Advantages of branched structure for proton transport under low humidity conditions in PEMFCs. J. Phys. Chem. C 2016, 120, 2574-2584. [CrossRef]

99. Nicotera, I.; Simari, C.; Boutsika, L.G.; Coppola, L.; Spyrou, K.; Enotiadis, A. NMR investigation on nanocomposite membranes based on organosilica layered materials bearing different functional groups for PEMFCs. Int. J. Hydrogen Energy 2017, 42, 7940-27949. [CrossRef]

100. Nicotera, I.; Kosma, V.; Simari, C.; Angioni, S.; Mustarelli, P.; Quartarone, E. Ion dynamics and mechanical properties of sulfonated polybenzimidazole membranes for high temperature proton exchange membrane fuel cells. J. Phys. Chem. C 2015, 119, 9745-9753. [CrossRef]

101. Aramendía, M.A.; Borau, V.; Jiménez, C.; Marinas, J.M.; Ruiz, J.R.; Urbano, F.J. Catalytic transfer hydrogenation of citral on calcined layered double hydroxides. Appl. Catal. Gen. 2001, 206, 95-101. [CrossRef]

102. Vaccari, A. Preparation and catalytic properties of cationic and anionic clays. Catal. Today 1998, 41, 53-71. [CrossRef]

103. Sels, B.F.; De Vos, D.E.; Jacobs, P.A. Hydrotalcite-like anionic clays in catalytic organic reactions. Catal. Rev. Sci. Eng. 2001, 43, 443-488. [CrossRef]

104. Climent, M.J.; Corma, A.; Iborra, S.; Primo, J. Base catalysis for fine chemical production: Claisen-schmidt condensation on zeolites and hydrocalcites for the production of chalcones and flavanones of pharmaceutical interest. J. Catal. 1995, 151, 60-66. [CrossRef]

105. Lufrano, E.; Simari, C.; Lo Vecchio, C.; Arico, A.S.; Baglio, V.; Nicotera, I. Barrier properties of sulfonated polysulfone/layered double hydroxides nanocomposite membrane for direct methanol fuel cell operating at high methanol concentrations. Int. J. Hydrogen Energy 2020, 45, 20647-20658. [CrossRef]

106. Xua, X.; Zhaoa, G.; Wang, H.; Li, X.; Feng, X.; Cheng, B.; Shi, L.; Kang, W.; Zhuang, X.; Yin, Y. Bio-inspired amino-acidfunctionalized cellulose whiskers incorporated into sulfonated polysulfone for proton exchange membrane. J. Power Sources 2019, 409, 123-131. [CrossRef]

107. Ozden, A.; Ercelik, M.; Devrim, Y.; Colpan, C.O.; Hamdullahpur, F. Evaluation of sulfonated polysulfone/zirconium hydrogen phosphate composite membranes for direct methanol fuel cells. Electrochim. Acta 2017, 256, 196-210. [CrossRef]

108. Krathumkhet, N.; Vongjitpimol, K.; Chuesutham, T.; Changkhamchom, S.; Phasuksom, K.; Sirivat, A.; Wattanakul, K. Preparation of sulfonated zeolite ZSM-5/sulfonated polysulfone composite membranes as PEM for direct methanol fuel cell application. Solid State Ion. 2018, 319, 278-284. [CrossRef]

109. Simari, C.; Lo Vecchio, C.; Baglio, V.; Nicotera, I. Sulfonated polyethersulfone/polyetheretherketone blend as high performing and cost-effective electrolyte membrane for direct methanol fuel cells. Renew. Energy 2020, 159, 336-345. [CrossRef]

110. Altaf, F.; Gill, R.; Batool, R.; Rehman, Z.-U.; Majeed, H.; Abbas, G.; Jacob, K. Synthesis and applicability study of novel poly(dopamine)-modified carbon nanotubes based polymer electrolyte membranes for direct methanol fuel cell. J. Environ. Chem. Eng. 2020, 8, 104118. [CrossRef]

111. McLean, G.F.; Niet, T.; Prince-Richard, S.; Djilali, N. An assessment of alkaline fuel cell technology. Int. J. Hydrogen Energy 2002, 27, 507-526. [CrossRef] 
112. Lu, S.; Pan, J.; Huang, A.; Zhuang, L.; Lu, J. Alkaline polymer electrolyte fuel cells completely free from noble metal catalysts. Proc. Natl. Acad. Sci. USA 2008, 105, 20611-20614. [CrossRef]

113. Hu, Q.; Li, G.; Pan, J.; Tan, L.; Lu, J.; Zhuang, L. Alkaline polymer electrolyte fuel cell with Ni-based anode and Co-based cathode. Int. J. Hydrogen Energy 2013, 38, 16264-16268. [CrossRef]

114. Ureña, N.; Pérez-Prior, M.T.; del Rio, C.; Várez, A.; Levenfeld, B. New amphiphilic semi-interpenetrating networks based on polysulfone for anion-exchange membrane fuel cells with improved alkaline and mechanical stabilities. Polymer 2021, 226, 123824. [CrossRef]

115. Bai, Y.; Yuan, Y.; Miao, L.; Lü, C. Functionalized rGO as covalent crosslinkers for constructing chemically stable polysulfone-based anion exchange membranes with enhanced ion conductivity. J. Membr. Sci. 2019, 570-571, 481-493. [CrossRef]

116. Li, T.; Yan, X.; Liu, J.; Wu, X.; Gong, X.; Zhen, D.; Sun, S.; Chen, W.; He, G. Friedel-Crafts alkylation route for preparation of pendent side chain imidazolium-functionalized polysulfone anion exchange membranes for fuel cells. J. Membr. Sci. 2019, 573, 157-166. [CrossRef]

117. Ma, L.; Qaisrani, N.A.; Hussain, M.; Li, L.; Jia, Y.; Ma, S.; Zhou, R.; Bai, L.; He, G.; Zhang, F. Cyclodextrin modified, multication cross-linked high performance anion exchange membranes for fuel cell application. J. Membr. Sci. 2020, 607, 118190. [CrossRef]

118. Iravaninia, M.; Azizi, S.; Rowshanzamir, S. A comprehensive study on the stability and ion transport in cross-linked anion exchange membranes based on polysulfone for solid alkaline fuel cells. Int. J. Hydrogen Energy 2017, 42, 17229-17241. [CrossRef]

119. Bai, Y.; Yuan, Y.; Yang, Y.; Lu, C. A facile fabrication of functionalized rGO crosslinked chemically stable polysulfone-based anion exchange membranes with enhanced performance. Int. J. Hydrogen Energy 2019, 44, 6618-6630. [CrossRef]

120. Liu, W.; Liang, N.; Peng, P.; Qu, R.; Chen, D.; Zhang, H. Anion-exchange membranes derived from quaternized polysulfone and exfoliated layered double hydroxide for fuel cells. J. Solid State Chem. 2017, 246, 324-328. [CrossRef]

121. Jiang, Y.; Wang, C.; Pan, J.; Sotto, A.; Shen, J. Constructing an internally cross-linked structure for polysulfone to improve dimensional stability and alkaline stability of high performance anion exchange membranes. Int. J. Hydrogen Energy 2019, 44, 8279-8289. [CrossRef]

122. Teresa Perez-Prior, M.; Urena, N.; Tannenberg, M.; del Rio, C.; Levenfeld, B. DABCO-Functionalized Polysulfones as AnionExchange Membranes for Fuel Cell Applications: Effect of Crosslinking. J. Polym. Sci. Part B Polym. Phys. 2017, 55, 1326-1336. [CrossRef]

123. Sharma, P.; Manohar, M.; Kumar, S.; Shahi, V.K. Highly charged and stable cross-linked polysulfone alkaline membrane for fuel cell applications: 4,4,-((3,3'-bis(chloromethyl)-(1,1'-biphenyl)-4,4-diyl) bis(oxy))dianiline (BCBD) a novel cross-linker. Int. J. Hydrogen Energy 2020, 45, 18693-18703. [CrossRef]

124. Msomi, P.F.; Nonjola, P.T.; Ndungu, P.G.; Ramontja, J. Poly (2, 6-dimethyl-1, 4-phenylene)/polysulfone anion exchange membrane blended with TiO2 with improved water uptake for alkaline fuel cell application. Int. J. Hydrogen Energy 2020, 45, 29465-29476. [CrossRef]

125. Rambabu, K.; Bharath, G.; Arangadi, A.F.; Velu, S.; Banat, F.; Show, P.L. $\mathrm{ZrO}_{2}$ incorporated polysulfone anion exchange membranes for fuel cell applications. Int. J. Hydrogen Energy 2020, 45, 29668-29680. [CrossRef] 